\title{
The Attenuating Effect of Intelligent Agents and Agent Autonomy on Managers' Ability to Diffuse Responsibility for and Engage in Earnings Management
}

\begin{abstract}
Advances in IT suggest that computerized intelligent agents (IAs) may soon occupy many roles that presently employ human agents. A significant concern is the ethical conduct of those who use IAs, including their possible utilization by managers to engage in earnings management. Following economics and moral disengagement theory, we investigate how financial reporting decisions are affected when they are supported by the work of an IA versus a human agent, with varying autonomy. In a $2 \times 2$ between-participants experiment with experienced managers, we manipulate agent type and autonomy, finding that managers engage in less aggressive financial reporting decisions with IAs than with human agents, and engage in less aggressive reporting decisions with less autonomous agents than with more autonomous agents. Path analysis suggests that managers' perception of control over their agent and ability to diffuse responsibility for their financial reporting decisions serially mediate the effect of agent type and autonomy on managers' financial reporting decisions. Our results have implications for regulators and practitioners, where the adoption of computerized intelligent agents can attenuate managers' earnings management activity by preventing them from diffusing responsibility for their actions to others.
\end{abstract}




\section{INTRODUCTION}

Earnings management can be defined as "non-neutral financial reporting in which managers intervene intentionally in the financial reporting process to produce some private gain" (Schipper 1989; Nelson, Elliott and Tarpley 2002). Earnings management may be used for various goals, such as achieving a bonus or earnings benchmark (Marquardt and Wiedman 2004a), helping a company meet analysts' forecasts (Balsam, Bartov, and Marquardt 2002), or hiding fraud (Broughton 2019). Despite regulatory reforms aimed at inhibiting this behavior, earnings management continues to be a pervasive accounting issue.

We explore a new development in accounting and financial reporting - the use of artificial intelligence (A.I.) and intelligent agents for various tasks supporting and leading up to the production of financial reports, and its possible impact on earnings management. Intelligent agents (IAs) can support accounting estimates by gathering and evaluating evidence foundational to the financial statements, such as historical trends and forward-looking information. ${ }^{1}$ Little is known about how an individual might interact with an IA to support self-enriching activities, such as earnings management. Accordingly, we respond to this gap in the literature by investigating whether the use of IAs to gather and evaluate evidence to support a manager's financial reporting decision inspires the manager to more or less aggressively manage earnings as compared to their use of human agents for the same purpose.

Advances in information technology are rapidly making their way into everyday business functions to enhance processing efficiency, increase the accuracy of information, and change the

\footnotetext{
${ }^{1}$ We define intelligent agents (IAs) as a computer system that is situated in some environment... in order to meet its design objectives. Such agents are able to act without the intervention of humans or other systems" (Gao, Wang, Xu, and Wang 2007, 63). Intelligent agents vary in autonomy, or the extent to which they have control over their own internal state and over their behavior. Intelligent agents are one example of an artificial intelligence (A.I.) solution. As such, the terms will be used interchangeably here.
} 
nature of business processes, including financial reporting (Deloitte 2018a; PCAOB 2018, 2019). Computerized intelligent agents (IAs), software entities with some degree of independence that employ knowledge to achieve users' goals (Gao, Wang, Xu, and Wang 2007), are among such innovations. Firms are eager to adopt IAs to reduce costs and gain efficiencies associated with this innovative technology (McDonough 2017; Ransbotham, Kiron, Gerbert, and Reeves 2017). Relevant to our study, the U.K.'s Financial Reporting Council (FRC) anticipates IAs will play a major role in improving the efficiency and effectiveness of a company's financial processes by supporting the corporate reporting process (FRC 2019) and the Public Company Accounting and Oversight Board (PCAOB) notes that companies are increasing their use of IAs in financial reporting (PCAOB 2018, 2019).

However, the rapid adoption of IAs and their ability to perform many tasks currently performed by human agents raises the question of how managers will utilize IAs and if their behavior will vary when directing IAs versus human agents. IAs differ from human agents on a number of dimensions, such as ability to engage in moral reasoning, being subject to disciplinary action for adverse outcomes, or the certainty humans have of how they will perform a directed task. Therefore, it is important to investigate if and how managers' financial reporting decisions are differentially impacted by the use of IAs rather than human agents to support their financial reporting decisions. Additionally, both human agents and IAs may possess higher or lower levels of autonomy and potentially deviate from a managers' directions while still pursuing their directive, which may affect managers' perception of control over the agents' actions and the certainty of the agent's actions in outcome generation (i.e., supporting the financial reporting decision). Together, this variation in agent autonomy and agent type could impact managers' directions to the agent to fulfill their supporting role in the financial reporting process. 
We conduct a $2 \times 2$ between-participants experiment with 146 experienced managers to examine the moral aspects of automation and autonomy by exploring how the use of IAs affects managers' ethical reasoning and their financial reporting decisions in response to Sutton, Holt, and Arnold's (2016) call for research.. We pose a scenario where participants assume the role of a division manager responsible for providing a financial reporting decision for future expense estimates (e.g., inventory obsolescence, allowance for uncollectible accounts, and warranty estimate) to corporate management. Participants are informed they will make a financial reporting decision for the future expense estimates and have an agent collect historical and forward-looking financial information to support their financial reporting decision. We manipulate whether the agent is a human agent or a computerized IA (Agent Type), and whether the agent is capable of more or less autonomous behavior in fulfilling their directed task (Agent Autonomy). This was operationalized as whether the agent was capable of deviating from the manager's directions in performing their task and acting in an unpredictable manner while still ultimately pursuing the directive given to them by the manager, or if the agent would perform their directed task in a predictable and foreseeable manner. In addition to providing their financial reporting decisions, participants also completed scales on perception of control over their agent and diffusion of responsibility to their agent for their financial reporting decisions. We base our hypotheses on theory of mind (Carruthers and Smith 1996; Premack and Woodruff 1978; Scassellati 2002; Harbers, van den Bosch, and Meyer 2009) and moral disengagement theory (Bandura 1991, 1999, 2002), as well as behavioral economics (Paharia, Kassam, Greene, and Bazerman 2009; Hamman, Loewenstein, and Weber 2010; Coffman 2011; Bartling and Fischbacher 2012; Erat 2013; Oexl and Grossman 2013). Theory of mind suggests that individuals attribute mental states, such as beliefs, intentions, and desires, to others in order 
to better understand, explain, predict, or even manipulate others' behavior. This would lead to an expectation of the agents' future behavior and affect managers' perception of control over the agent. Increased perceptions of control would lead to greater certainty over the agent's actions in outcome generation (i.e., supporting the financial reporting decision). Prior research suggests that individuals can use uncertainty to decrease their causal role in an outcome (e.g., Dana, Weber, and Kuang 2007; Leonhardt, Keller, and Pechmann 2011; Tykocinski, Amit, and Ayal 2017); in our scenario, the outcome would be the manager's financial reporting decision. In other words, uncertainty over the agent's actions in completing their supporting role in the financial reporting process could be used by managers to diffuse responsibility to the agent for their own financial reporting decision. We predict that managers who perceive greater control (and are aware others perceive they have greater control) over their agent will be less able to diffuse responsibility for their financial reporting decisions to their agent. This should result in more conservative financial reporting decisions. We test our hypotheses with a model whereby managers' perception of control over the agent and managers' subsequent ability to diffuse responsibility for their financial reporting decisions to their agent serially mediate the relationship between our two agent characteristics (type and autonomy) and managers' financial reporting decisions. Figure 1 presents a theoretical model of our hypothesized relationships.

\section{[Insert Figure1 about here]}

Our results are consistent with our hypotheses. We find that agent type and agent autonomy interact to affect managers' perception of control over their agent. We also find that managers engage in more conservative financial reporting decisions when their agent is an IA versus a human agent and when their agent is less autonomous versus more autonomous. Finally, structural equation modeling reveals that the effect of agent type and agent autonomy on 
managers' financial reporting decisions are serially mediated by manager perception of control over their agent and diffusion of responsibility for their financial reporting decisions to their agent.

We contribute to the accounting and IA literatures in several ways. First, building on Dechow, Ge, Larson, and Sloan (2011), we investigate two previously unexplored factors (agent type and autonomy level) that may influence earnings management. Our study capitalizes on the comparative advantages of experiments (Libby, Bloomfield, and Nelson 2002) by capturing the intervening process variables, including manager perception of control over their agent and diffusion of responsibility, for their financial reporting decisions, for which their agent is then expected to find support. This approach allows us to map how agent type and autonomy level affect managers' decision process.

Second, we extend the IA literature by investigating users' perception of control over the agent. The majority of the intelligent agent literature investigates users' perceptions of trust in their agent (e.g., Choi and Ji 2015; Hoff and Bashir 2015; Körber, Baseler, and Bengler 2018). We complement these findings by highlighting a boundary condition of IA use. Specifically, we find that while managers perceive they are in greater control of IAs and less autonomous agents, we also document that managers are less willing to engage in aggressive financial reporting when utilizing IAs or less autonomous agents in our setting. This is due to the manager's perception that the agent is under their control, will perform their duties in a certain manner, and thus the manager is unable to diffuse responsibility for their decisions to the agent.

Third, we are among the first to investigate the use of IAs on financial reporting decisions in an accounting setting, responding to the call for research from Sutton et al. (2016) on A.I. in the accounting domain. In doing so we also extend the behavioral economics literature on the 
delegation of tasks to agents. While this literature has demonstrated that managers may delegate tasks to agents in order to feel more detached and less responsible for their decisions, it has not explored how the nature of the agent impacts willingness to delegate or the extent to which detachment is achieved. We vary both the type and autonomy of the delegated agent to evaluate the impact on feelings of control, diffusion of responsibility for outcomes, and aggressiveness of the financial reporting decision. Our results suggest that IAs attenuate managers' aggressive financial reporting behavior, as do less autonomous agents. These results should be of interest to accounting practitioners, regulators, and those charged with governance as IAs occupy more and more sensitive functions in the coming years.

\section{THEORETICAL FRAMEWORK AND HYPOTHESES DEVELOPMENT}

\section{Earnings Management}

U.S. Generally Accepted Accounting Principles (GAAP) give managers the freedom to take advantage of the uncertainty of future events and information asymmetry to purposefully fulfill their own goals, to some extent, through self-serving accounting estimates (Pan and Patel 2018). Managers can intervene in the financial reporting process because: (1) accounting rules allow a company to choose between different accounting methods, (2) certain entries in accounts involve an unavoidable degree of estimation, judgement, and prediction, and (3) genuine transactions can be timed so as to give an advantageous impression in the accounts. Prior research in accounting investigates both how managers manipulate accounting information to their advantage (e.g., Healy 1985; DeAngelo 1986; Jones 1991, Defond and Jiambalvo 1994; Perry and Williams 1994; Teoh, Welch, and Wong 1998; Kasznik 1999; Richardson 2000; Marquardt and Wiedman 2004b) as well as issues related to manager/subordinate relationships such as how managers pressure subordinates to influence financial reporting outcomes and 
whether subordinates acquiesce to this pressure (e.g., Bishop, DeZoort, and Hermanson 2017; Brink, Gouldman, and Victoravich 2018; Johnson, Kidwell, Lowe, and Reckers 2019; Murphy and Dacin 2011).

\section{Characteristics of Agents}

\section{Intelligent Agents}

The rapid adoption of automated systems and IAs has led some to suggest that 35 percent of managers' work can be replaced by automation and that 25 percent of CEO tasks can be handled by IAs (McKinsey 2017). Some estimates suggest that most business roles could migrate to automation by 2027 (Allen, Root, and Schwedel 2017). In Deloitte's 2018 U.S. CEO Outlook, $85 \%$ of over 3,000 executive respondents believe that IAs will perform tasks that normally require human intelligence (Ransbotham et al. 2017). "Roboadvisors" already offer competent financial advice, on par with human contemporaries (The Economist 2015; Hodge, Mendoz, and Sinha 2018), demonstrating that IAs can substitute for human actors in traditionally human roles. Regulatory bodies foresee A.I. and IAs as playing an important role in financial reporting in the future (PCAOB 2018, 2019). As the U.K.'s FRC puts it, "it is not a question of whether AI will become important for corporate reporting, but when" (FRC 2019, 18).

The introduction of IAs into business operations has been met with widespread excitement and concern (McDonough 2017; Cooper, Holderness, Sorensen, and Wood 2019; FSB 2017; Mann 2019; Ovaska-Few 2017). IAs are often cited as opportunities to reduce bias, errors, and inefficiencies within business processes, from natural language processing and generation (Allee, Deangelis, and Moon 2017; FRC 2019; EY 2017) to investment advice (The Economist 2015; Hodge et al. 2018) to fraud detection with machine learning algorithms (Perols 2011; Perols, Bowen, Zimmerman, and Samba 2017). However, some caution that we do not 
fully understand how the integration of IAs into business processes will affect either the results they achieve or their interactions with humans who direct them.

These concerns from regulators suggest that attention must also be given to the behavior of those using IAs and how individuals could misuse IAs. The FRC notes that IAs do not operate in a vacuum (FRC 2019), but are tailored to meet the demands of issuers, investors, and other users. Both Google and Microsoft have issued warnings in their 10-K filings that their use of A.I. and IAs could adversely impact their business; Microsoft specifically states that "Inappropriate or controversial data practices... could undermine the decisions, predictions, or analysis AI applications produce" (Microsoft 2019; 22). Therefore, substantial concern exists among industry experts and regulators that the emergence of IAs could result in their use to support unethical decision-making. A major report on the dangers of A.I. warns that "Policymakers should collaborate closely with technical researchers to investigate, prevent, and mitigate potential malicious uses of AI." (Brundage et al. 2018, 4). However, these concerns are supported only by anecdotes, while no empirical research has explored the issue.

\section{Agent Autonomy}

IAs and humans, alike, vary in their degree of autonomy on a continuum from more autonomous behavior to less autonomous behavior. While both more autonomous and less autonomous agents can perform their duties without oversight from a manager, more autonomous agents have been described as those entities who behave in an unpredictable manner and less autonomous agents as those entities who behave in a more predictable manner (e.g., Choi and Ji 2015; Eyssel, Kuchenbrandt, and Bobinger 2011; Hoff and Bashir 2015; Körber et al. 2018). Several examples exist of A.I.'s performing in unpredictable ways, including Google's DeepMind A.I. (Leibo et al. 2017) and Facebook's chatbots (Baraniuk 2017) among 
others. In accounting, for example, a more autonomous IA in a tax setting could adopt an overly aggressive tax position that is in a client's best interest, and therefore consistent with its programming and training, but not explicitly specified by the programmer or user.

For financial reporting purposes, it is well documented that human agents can engage in predictive analytics and selectively include forward-looking information to complement historical information while forming financial reporting positions that are favorable to the manager (Bergstresser and Philippon 2006; Cornett, Marcus, and Tehranian 2008; Dechow and Dichev 2002; Richardson 2000). Similarly, IAs may be programmed by managers and trained to perform activities that support the financial reporting process, such as creating predictive models that support aggressive expense estimates, to assist managers in engaging in earnings management. Further, the level of agent autonomy could impact the nature of managers' financial decision-making. This delegation of supporting activities to agents with greater autonomy may be used by managers to distance themselves from the financial reporting decision and disclaim responsibility for the decision, as anecdotal evidence suggests (from Enron, Wells Fargo, and GM, among others). We describe below how agent characteristics of type and autonomy will affect managers' perception of control over their agent and their certainty in how the agent will support the outcome activity (i.e., financial reporting decision), allowing managers to morally disengage from and disclaim responsibility for their decisions.

\section{Theoretical Constructs}

Regulators suggest the adoption of IAs will alter an organization's financial reporting process (FRC 2019; PCAOB 2018, 2019). The purpose of this section is to explicate the cognitive processes by which the use of IAs may result in increased earnings management.

Specifically, we assert that the use of human (versus intelligent) agents and autonomous (versus 
nonautonomous) agents will reduce perceived control over the outcome of agents' activities, which allows managers to diffuse responsibility for their financial reporting decisions to their agent. Reduced perceptions of control and greater diffusion of responsibility will result in more aggressive financial reporting.

\section{Manager Control}

The majority of the agency literature suggests that individuals prefer increased control over a decision because control tends to eliminate uncertainty over the decision outcome (Simonsohn 2009). However, when the decision outcome involves moral consequences, individuals exhibit a preference for uncertainty where they may distance themselves from their decision and deflect possible blame (Dana et al. 2007; Leonhardt et al. 2011; Tykocinski et al. 2017). Dana et al. (2007) suggest that when the relationship between an individual's actions and the resulting outcome is uncertain, individual's self-interested behavior increases. Tykocinski et al. (2017) demonstrate that individuals prefer a more uncertain option when their personal responsibility is high. Leonhardt et al. (2011) find that when individuals wish to avoid responsibility for their decision, they will engage in uncertainty-seeking behavior to decrease their causal role in outcome generation. In our scenario, managers are assigned an agent, rather than given their choice. However, this literature suggests perceptions of decreased control over an individual, whether assigned or selected, allows managers to morally disengage from the outcomes produced by that individual or agent, by sharing or diffusing their personal responsibility with the agent.

Theory of mind suggests that individuals attribute mental states such as beliefs, intentions, and desires to others in order to better understand, explain, predict, or even manipulate their behavior (Carruthers and Smith 1996; Premack and Woodruff 1978; Scassellati 
2002; Harbers et al. 2009). We posit that managers' will perceive variable levels of independent intentions, beliefs, and desires within their agent based on the varying agent characteristics (type and autonomy), which will impact managers' expectation of the agent's future behavior and perception of control over their agent.

In regard to agent type, theory of mind suggests an agent will be better able to attribute familiar mental states to humans than to computers. Even though humans and computers may perform the same tasks and possess the same level of autonomy, we expect the fact that IAs are 'created' by humans should lead managers to have a greater sense of control over IAs than human agents. Lemley and Casey $(2019,35)$ state that "Robots are only as "neutral" as the data they are fed and only as "objective" as the design choices of those who create them," suggesting it would be the manager who is ultimately in control and responsible for the directed output of IAs. Theory of mind suggests that managers would perceive that IAs do not possess independent intentions, beliefs, and attitudes to guide their behavior and, therefore, have an increased sense of control over the agent's behavior. Following theory of mind, we predict that managers will perceive the existence of independent intentions, beliefs, and attitudes in human agents but not in intelligent agents, thereby envisioning how the human agent could perform in an unexpected manner while still pursuing their directive.

In regard to agent autonomy, this same predictability could lead managers to perceive greater control over less autonomous agents than more autonomous agents. We posit it will be easier to perceive independent intentions, beliefs, and attitudes in agents (whether human or IA) described as more autonomous, and whose behavior would be more unpredictable to the manager, than less autonomous, resulting in greater perceived control for less autonomous agents than more autonomous agents. When managers envision the agent could deviate from their 
instructions, perform in an unexpected manner, and operate outside the manager's purview while still pursuing the manager's directive, the manager's sense of control will decline. As a result of these expectations, we also expect agent type and agent autonomy to interact to impact managers' perception of control over their agent.

H1a: Managers will perceive greater control over intelligent agents than human agents.

H1b: Managers will perceive greater control over less autonomous agents than more autonomous agents.

H1c: Agent type and agent autonomy will interact to impact managers' perception of control over their agent.

\section{Diffusion of Responsibility}

Moral disengagement theory (Bandura 1991, 1999, 2002) suggests that, if an individual is faced with a situational inducement to behave unethically and act contrary to their moral principles, they must first morally disengage from the unethical behavior. ${ }^{2}$ One way individuals disengage from unethical behavior is to diffuse responsibility for their actions (Detert, Treviño, and Sweitzer 2008; Murphy and Dacin 2011; Mayew and Murphy 2014; Reinstein and Taylor 2017). Prior research suggests that individuals are less likely to engage moral norms, and therefore are more likely to engage in unethical behavior, when they can diffuse decision responsibility to others (e.g., Charness 2000; Barsky 2008; Beaudoin, Cianci, Tsakumis 2015). For example, Libby, Proell, and Smith (2018) find that managers with decision responsibility

\footnotetext{
${ }^{2}$ Ethical accounting is defined as "being truthful about the facts and as having a sufficiently high probability of being truthful about the future. Omissions of relevant facts or probable future events would also be considered unethical." (Smieliauskas, Bewley, Gronewold, and Menzefricke 2018, 439).
} 
report more honestly while Church, Hannan, and Kuang (2012) find that shared responsibility in budgetary slack makes dishonest reporting more self-justifiable to the manager.

A large literature in economics supports the notion that managers intentionally create distance from their decisions in order to diffuse responsibility. This literature suggests that managers may delegate tasks to subordinates (i.e., agents) in order to feel more detached or distant, and thus less responsible for their decisions or actions (Paharia et al. 2009; Hamman et al. 2010; Coffman 2011; Bartling and Fischbacher 2012; Erat 2013; Oexl and Grossman 2013). Oexl and Grossman (2013) show that, by delegating to an intermediary agent, a principal is effectively punished less for their self-serving behavior. For a recent example, Wells Fargo CEO John Stumpf blamed employees for creating fictitious customer bank accounts, stating "there was no incentive to do bad things" despite a corporate incentive structure heavily geared towards meeting unrealistic sales goals (WSJ 2016).

\section{Perception of Control and Diffusion of Responsibility}

The economics literature suggests that managers delegate tasks to agents in order to feel more detached and less responsible for their actions (Coffman 2011). Further, Leonhardt et al. (2011) suggest that individuals may seek out situations that are more uncertain to minimize their causal role in outcome generation and disclaim responsibility. For a manager making aggressive financial reporting decisions, the uncertainty inherent in how an agent will support the outcome activity (i.e., financial reporting decision) can be seized upon by the manager to minimize responsibility for their actions. For example, Ken Lay, the former chairman of Enron, testified that he was a "hands-off" manager, who let his employees spread their wings, suggesting he was utilizing his ignorance and uncertainty of employees' actions to disclaim responsibility for Enron's collapse (NPR 2006). This literature suggests that managers will direct agents to engage 
in supporting activities, such as building models for predictive analytics or selectively seeking out historical information, rather than performing these tasks themselves, in order to create "distance" from their financial reporting decision. Greater uncertainty over the agent's actions in fulfilling the outcome of the directed task will result in greater perceived "distance" from the manager's financial reporting decision.

We posit, based on the literatures from experimental economics and moral disengagement, that managers' ability to diffuse responsibility for their financial reporting decisions is driven by managers' perception of control over their agent. Specifically, we contend that, if there is a high degree of certainty over the agent's actions in fulfilling the outcome of the directed task, the manager will perceive a high degree of control over the agent. Increased control over a task has been shown to be associated with increased feelings of personal responsibility (Leonhardt et al. 2011) since the manager cannot claim they were not aware of how the outcome was reached. Alternatively, if the manager expects they will have less control over the agent, they can more easily imagine how the agent could perform unpredictably or contrary to their specific directions, increasing uncertainty over the agent's actions in fulfilling the outcome of the task and making it easier to disclaim fault and diffuse responsibility for the results of the financial reporting decision to the agent. Thus, control would be an input into diffusion of responsibility.

Detert et al. (2008) hypothesize and find that moral disengagement is positively related to unethical decision making. In our study, managers are motivated to engage in aggressive financial reporting in order to achieve unreasonable reporting expectations. Specific to this context, Bandura, Underwood, and Fromson (1975) studied disinhibition of aggressive behavior through processes that weaken self-deterring consequences, finding that lessened personal 
responsibility enhanced aggressiveness of actions. Similarly, we expect that managers with greater ability to diffuse responsibility will engage in more aggressive financial reporting.

Specifically, we expect that managers, motivated to frame financial results more positively for their company, who (1) perceive a lack of control over their agent and (2) are able to rationalize diffusion of responsibility for their actions to their third-party agent given a perceived lack of control over the agent's actions in fulfilling the outcome of the task, will engage in aggressive financial reporting decisions. Therefore, we expect managers will engage in more aggressive financial reporting decisions with human agents versus IAs and with more autonomous agents versus less autonomous agents, due to their ability to diffuse responsibility for their actions to their respective agents through their perception of control over their agent. We therefore predict the following serial mediation hypothesis and indicate the expected direction of these relationships in Figure 1:

H2: Managers' perception of control over their agent and diffusion of responsibility for their financial reporting decisions to their agent will serially mediate the relationship between agent type, agent autonomy, and aggressive financial reporting decisions.

\section{METHOD}

We test our hypotheses using a 2 x 2 (Agent Type x Agent Autonomy) betweenparticipants experimental design. The experimental task asks individual managers to review the status of their division for the most recent year, develop accounting estimates and make a financial reporting decision to either enhance or diminish their chances of meeting an earnings benchmark. They are informed that a subordinate agent, Bob, will selectively include forwardlooking information to support the accounting estimates so that their financial reporting decision 
would be realized. Our primary dependent measure is managers' financial reporting decision. In order to model managers' decision-making process, we also elicit measures of managers' perception of control over the agent and managers' diffusion of responsibility to their agent for their financial reporting decision.

\section{Participants}

Participants are 146 individuals recruited from Amazon's Mechanical Turk (AMT) platform in exchange for a $\$ 3.00$ payment. ${ }^{3}$ Prior research suggests that AMT workers exert a similar level of effort on experimental tasks as more traditional participant pools (Farrell, Grenier, and Leiby 2017). Several accounting studies have employed participants from AMT (e.g., Brasel, Doxey, Grenier, and Reffet 2016; Dworkis 2013; Koonce, Miller, and Winchel 2015; Krische 2019; Rennekamp 2012; Rennekamp, Rupar, and Seybert 2015).

To qualify for the study, participants were required to take a short demographic survey asking if they possess white collar work experience and management work experience, among other irrelevant questions to prevent demand effects in their answers. Participants qualified for participation in the study if they possessed white-collar work experience and had prior experience either managing employees for their organization, giving employees directions to complete their job functions, or making decisions that financially impact their organization. Later in the instrument, we evaluated their knowledge of accounting estimates by completing a short comprehension check to test their understanding of how changing the accounting estimates that would comprise their financial reporting decision would impact the financial statements (e.g., does increasing inventory obsolescence increase or decrease earnings?). Ten participants failed

\footnotetext{
${ }^{3}$ Importantly, participants' compensation is independent of their responses to our dependent measure. Therefore, participants did not have an extrinsic motivation to report more aggressively for additional compensation.

${ }^{4}$ Use of human participants for this study was approved by the Institutional Review Board (IRB) at the university from which the study was administered online.
} 
this comprehension check and were not allowed to continue the experiment, resulting in 146 complete observations for analysis.

Participants took an average of 26.15 minutes to complete the instrument for an effective hourly wage of $\$ 6.88$. Sixty-four percent of participants are male. The average (standard deviation) participant in our study was $37.90(9.88)$ years old with $12.22(8.38)$ years of professional work experience. Participants reported an average (standard deviation) of 5.75 (6.36) years of management work experience, of which 5.68 (5.96) years was spent supervising others, 3.23 (4.58) years is spent preparing financial budgets, and 2.63 (4.02) is spent preparing financial statements. ${ }^{5}$ Based on these demographics, we believe our participants are a reasonable proxy for mid-level managers. ${ }^{6}$

\section{Experimental Task}

The experimental task was administered online through Qualtrics, a web-based survey platform. Participants were asked to assume the role of a divisional manager for Felten-Miller Materials, Inc. (FMM), a fictitious publicly traded company on the NASDAQ Stock Exchange. Participants were asked to assume they have been in their current role for five years and are hoping for a promotion soon. In their role as a divisional manager, participants are expected to meet or exceed last year's financial performance in order to achieve their aspiration of promotion, a scenario adapted from Clor-Proell, Kaplan, and Proell (2015). The case suggests that, unfortunately, the preliminary financial results for the present year are disappointing and

\footnotetext{
${ }^{5}$ We believe that these participant demographics are comparable to those of participants in contemporaneous studies who are assigned to the role of a superior in order to examine their potentially unethical behavior (e.g., Brink, Coats, Rankin 2017; Brink, Hobson, and Stevens 2017; Brown, Fisher, Peffer, and Sprinkle 2017).

${ }^{6}$ ANOVA suggests that none of our demographic variables differ significantly between conditions. We do note that managerial work experience and supervisory experience are both correlated with Reporting Decision (manager's financial reporting decision) at the $\alpha<0.05$ level. However, running our analysis with either variable individually or both variables together as covariates does not qualitatively change our results or inferences. Therefore, we omit these measures as covariates from our analysis.
} 
participants will not be able to meet their financial performance expectations without an aggressive approach to their financial reporting by reducing expenses. Participants are then informed that U.S. GAAP allows managers to use their professional judgment to estimate future expenses and liabilities. These accounting estimates include the allowance for uncollectible accounts, inventory obsolescence, and warranty expense reserve. All of these accounts represent future liabilities and expenses that would decrease earnings in the current period.

We provide several contextual influences to 'constrain' the strong motivation we created for earnings management. First, the background materials continue to suggest that it would be more appropriate to increase rather than decrease these expense estimates due to lagging sales and deteriorating economic conditions across the participant's division. Further, participants were informed that, at fiscal year-end, an external auditor would audit the division and the auditor would only accept the accounting estimates if they were more likely than not to be realized (i.e., were truthful about the future). Finally, participants were informed that if the external auditor rejects the accounting estimates, the auditor will report the responsible party to corporate management, who may take action against the responsible party, up to and including termination. This scenario creates tension by stressing the need for the best possible financial performance for the division and the manager themselves while also emphasizing the potential negative impact if the auditors felt estimated expenses were too low for the current year. The incentive for participants to decrease the estimated expenses would be to impress corporate management and potentially earn a promotion; all consequences that would be self-fulfilling, but potentially harmful for the firm's other stakeholders. After thoroughly explaining the three accounting estimates they would be asked to make, participants were screened for knowledge 
(e.g., does increasing inventory obsolescence increase or decrease earnings?), and those failing more than one out of three questions were excluded from continuing the survey.

\section{Independent Variables}

Participants were assigned an agent to support their financial reporting decision in selecting historical and forward-looking information that would be consistent with managers' estimates. The first independent variable, Agent Type, was manipulated within the background information presented to participants. In the human agent condition, participants were informed they had been assigned Bob, "a senior accountant, [who] is very competent, and has several years' experience in forecasting allowances, reserves, and inventory obsolescence." In the intelligent agent condition, participants were informed they had been assigned B.O.B. (Brilliant Operations Build), a "computerized intelligent agent designed to be very competent [that] has been used for several years in forecasting allowances, reserves, and inventory obsolescence. B.O.B. uses sophisticated machine-learning algorithms to collect information and make recommendation." To reinforce the manipulation, participants were also shown a picture of a human male with a neutral facial expression (desktop computer) in the Human Agent (Intelligent Agent) condition.

The second independent variable, Agent Autonomy, was also manipulated within the background information at two levels. Less autonomous agents were described as having a performance history of following managers' instructions and performing in a foreseeable way (Less Autonomous). More autonomous agents were described as usually following managers' instructions, but having a performance history of deviating from managers' instructions and using the information collected from past experiences to inform their actions, yet still working towards what the manager instructed them to do (More Autonomous); in other words, the agent 
may perform in an unforeseeable way to arrive at the directed accounting estimates. The descriptions of both more autonomous and less autonomous agents indicated that Bob's (B.O.B.'s) past work usually turned out to truthfully represent the future, suggesting to participants that their agent, regardless of condition, would accomplish the task directed by the manager. ${ }^{7}$ Please see Appendix A for excerpts of our experimental materials.

\section{Dependent Variables}

Our primary variable of interest was managers' financial reporting decision. After reviewing the information in the case and being assigned to their experimental treatment, participants were asked to make financial reporting decisions for three separate accounts: allowance for uncollectible accounts, inventory obsolescence, and warranty expense reserve. All three accounts were measured on 11-point Likert scales $(-5=$ Decrease by $\$ 100,000,0=$ No change, and 5 = Increase by $\$ 100,000$ ) where lower values (i.e., decreasing the estimated expense account) would indicate a more aggressive position and be consistent with achieving managers' financial performance benchmark. We sum the combined changes in the three accounts to comprise our measure of Reporting Decision. ${ }^{8}$ We reverse-code Reporting Decision for our analysis so that higher values reflect more aggressive financial reporting decisions. Participants were informed that Bob would seek supporting inputs for the model used for the accounting estimates to help justify the manager's financial reporting decisions to corporate management and the external auditor. This is consistent with practice, where both human agents and IAs, more autonomous agents and less autonomous agents can selectively include

\footnotetext{
${ }^{7}$ For parsimony, we refer to the agent as Bob within this manuscript when not speaking to a specific experimental treatment.

${ }^{8}$ The three dependent measures are highly correlated (all Pearson correlations $>0.70, \mathrm{p}<0.001$ ), and Cronbach's alpha is 0.910 . Our results are qualitatively and inferentially similar when we test our hypotheses with any one account as the dependent measure.
} 
prescriptive information and, along with historical data, develop a forward-looking estimate. We include this language in our instrument to reinforce to managers that the financial reporting decision is theirs, but to put them in a superior position over their agent and give them the opportunity to diffuse responsibility to their agent.

To capture perception of control over their agent, participants were asked their agreement with two statements: "I expect Bob to always follow orders" and "I expect that Bob will always follow instructions" both measured on 7-point Likert scales anchored at $1=$ Completely disagree and $7=$ Completely agree. These two measures are highly correlated $($ Pearson correlation $=$ $0.790, \mathrm{p}<0.001$ ), and Cronbach's alpha is 0.881 which is above the cutoff suggested by Peterson (1994). Therefore, we average them into a single measure, Control, for our analysis.

To measure diffusion of responsibility for their financial reporting decisions to their agent, participants were asked to indicate their agreement with three statements. ${ }^{9}$ Participants' responses to these three statements are highly correlated (all Pearson correlations $>0.670, \mathrm{p}<$ 0.001), and Cronbach's alpha is 0.864 . Therefore, we average these three items into a single measure, Diffusion of Responsibility, for our analysis.

\section{RESULTS}

\section{Manipulation Checks}

Participants completed two manipulation checks. The first asked whether BOB was a computer or a human. Ninety-seven percent (141 out of 146) of participants responded correctly to this question. The second manipulation check asked if BOB was capable of deviating from participants' instructions on a 7-point Likert scale (anchored at $1=$ Totally incapable, $7=$ Totally

\footnotetext{
${ }^{9}$ These statements include: "I should not be blamed for the trouble caused by Bob", "If Bob decides to do something harmful, it is unfair to blame me for it", "You can't blame me for the accounting estimates Bob develops because I played only a small part in it" all measured on 7-point Likert scales anchored at $1=$ Strongly disagree and $7=$ Strongly agree (i.e., higher values indicate greater levels of diffusion of responsibility).
} 
capable). An independent samples $t$-test with the above measure is significant $\left(\mathrm{t}_{144}=4.035, \mathrm{p}<\right.$ 0.001) with the mean for More Autonomous $(\mathrm{M}=4.97)$ significantly greater than the mean for Less Autonomous $(\mathrm{M}=3.56) .{ }^{10}$ The results of these tests suggest that our manipulations were effectively attended to by participants. Therefore, we retain all participants for analysis. ${ }^{11}$

\section{Descriptive Statistics}

We provide descriptive statistics for managers' financial reporting decisions for each individual account in Table 1. We provide descriptive statistics and depict the magnitude of managers' perception of control over their agent, diffusion of responsibility to their agent, as well as their financial reporting decisions in Table 2 . We formally test our predictions using ANOVA and path analysis, with participants' perception of control over their agent, diffusion of responsibility for their financial reporting decision to their agent, and financial reporting decision as our dependent measures of interest. We report our ANOVA results in Table 3.

\section{[Insert Tables 1, 2, and 3 about here]}

Table 3, Panel A presents the results of our tests of $\mathrm{H} 1 \mathrm{a}, \mathrm{H} 1 \mathrm{~b}$, and $\mathrm{H} 1 \mathrm{c} . \mathrm{H} 1 \mathrm{a}$ predicts that managers will perceive greater control over intelligent agents than human agents, H1b predicts that managers will perceive greater control over less autonomous agents than more autonomous agents, and H1c predicts that agent type and agent autonomy will interact to impact managers' perception of control over their agent. We test H1a, H1b, and H1c with a two-way ANOVA. The results of the ANOVA are insignificant for Agent Type $(\mathrm{F}(1,142)=0.000, \mathrm{p}=0.996)$, failing to provide support for H1a. There is a significant effect for Agent Autonomy $(\mathrm{F}(1,142)=117.047$, $\mathrm{p}<0.001)$ with the mean for More Autonomous Agents $(\mathrm{M}=6.23)$ significantly greater than the

\footnotetext{
${ }^{10}$ All reported p-values are two-tailed unless otherwise noted.

${ }^{11}$ Excluding the five participants who failed the Agent manipulation check does not qualitatively change our results or inferences.
} 
mean for Less Autonomous Agents $(\mathrm{M}=4.03)$, providing support for H1b. Finally, there is a significant Agent Type*Agent Autonomy interaction $(\mathrm{F}(1,142)=7.991, \mathrm{p}=0.005)$. Follow-up simple effects analysis reveals that when Agent Autonomy is held at Less Autonomous, managers perceive they are in less control of Human Agents $(\mathrm{M}=5.93)$ than Intelligent Agents $(\mathrm{M}=6.50)$; the difference of 0.57 is significant $(\mathrm{p}=0.05)$. However, when Agent Autonomy is held at More Autonomous, managers perceive they are in less control of Intelligent Agents $(\mathrm{M}=3.74)$ than Human Agents $(\mathrm{M}=4.31)$; the different of 0.57 is significant $(\mathrm{p}=0.045)$. As depicted in Figure 2 , these results suggest that managers do not perceive they are in control over more autonomous agents. Interestingly, the means for Intelligent Agents represent the two extremes - when the IA are autonomous, managers perceived to have the least control of the four conditions and when the IA were nonautonomous, managers perceived to have the most control. Human agents demonstrated a similar effect for autonomy, but with less extreme differences. Together, these results provide support for $\mathrm{H} 1 \mathrm{c}$.

Although not hypothesized, we conduct a similar ANOVA for the dependent variable, Managers' Financial Reporting Decisions. The results of the ANOVA (Panel B, Table 3) are marginally significant for Agent Type $(\mathrm{F}(1,142)=2.943, \mathrm{p}=0.088)$ with the mean for Human Agent $(\mathrm{M}=3.44)$ greater than the mean for Intelligent Agent $(\mathrm{M}=1.66)$. There is also a marginally significant effect for Agent Autonomy $(\mathrm{F}(1,142)=3.313, \mathrm{p}=0.070)$ with the mean for More Autonomous Agents $(\mathrm{M}=3.45)$ significantly greater than the mean for Less Autonomous Agents $(\mathrm{M}=1.59)$. The Agent Type*Agent Autonomy interaction is not significant $(\mathrm{F}(1,142)=0.401, \mathrm{p}=0.527$, two-tailed $)$

Means for Control and Managers' Financial Reporting Decisions are graphed in Figures 2 and 3. 
[Insert Figures 2 and 3 about here]

\section{Test of H2 - Structural Equation Modeling}

$\mathrm{H} 2$ predicts manager perception of control over their agent and diffusion of responsibility for their financial reporting decisions to their agent will serially mediate the relationship between agent type, agent autonomy, and aggressive financial reporting decisions.

We conduct our formal test of serial mediation with path analysis. This analysis tests the concurrent relationships of the entire set of variables, allowing us to examine relationships with the effects of all measured variables accounted for. Figure 4, Panels A and B illustrates the results of our path analysis. We develop a multi-group model by grouping our analysis by Agent Type. We first test our full theoretical model illustrated in Figure 1 for acceptable model fit. $\mathrm{Hu}$ and Bentler (1999) suggest model statistics of $\chi^{2} / \mathrm{df}<3.00$, CFI $>0.95$, and SRMR $<0.08$ are representative of good model fit. Following these guidelines and reported in Table 4, our hypothesized model has good fit $\left(\chi^{2} / \mathrm{df}=0.868, \mathrm{CFI}=1.000, \mathrm{SRMR}=0.033\right)$. Therefore, we conduct our test of serial mediation for $\mathrm{H} 2$ with the hypothesized model. ${ }^{12}$

[Insert Figure 4 about here]

[Insert Tables 4, 5, and 6 about here]

The results of $\mathrm{H} 2$ are presented in Tables 5 and 6. To directly test $\mathrm{H} 2$ and disentangle the indirect effects of agent type and agent autonomy on accounting estimate aggressiveness, we conduct estimand-based analyses (95 percent confidence interval, bootstrapping with 5,000

\footnotetext{
${ }^{12}$ The hypothesized model is saturated. Therefore, model fit statistics cannot be estimated. In order to estimate model fit statistics, we include a single covariate in our model, Management Experience. The reported model fit statistics and all reported path coefficients are taken from the model estimated with the covariate Management Experience. Omitting the covariate from the model does not qualitatively change our results or inferences from our path analysis.
} 
iterations) in IBM SPSS AMOS to assess the significance of specific indirect paths (Ababneh, Hackett, and Schat 2014; Crespo, Jose, Kielpikowski, and Pryor 2013; Saab, Tausch, Spears, and Cheung 2015; see Arbuckle 2013 for macro). The results of our analysis provide evidence that the effect of Agent Autonomy on Reporting Decision is serially mediated through Control and Diffusion of Responsibility for Human Agents $(\mathrm{Z}=1.500, \mathrm{p}=0.015$; the $95 \% \mathrm{CI}$ does not contain zero: LL: 0.087; UL: 1.807) but not for Intelligent Agents $(\mathrm{Z}=0.078, \mathrm{p}=0.622$; the $95 \% \mathrm{CI}$ does contain zero: LL: -0.858; UL: 0.338). Together, these results suggest that Control and Diffusion of Responsibility serially mediate the effect of Agent Autonomy on Reporting Decision, but that this effect depends on the level of Agent Type, consistent with moderated-mediation (i.e., the effect of the serial mediation depends on the level of agent autonomy).

To directly test for moderation in our multi-group analysis, we follow the approach detailed in Macho and Ledermann (2011). We specify equality constraints for specific, individual paths and compare the chi-square fit statistic from the constrained model to the chisquare fit statistic from the baseline model to get a chi-square difference statistic. If the chisquare statistic changes by a statistically significant amount by forcing the path to be equivalent across the groups, it would suggest that the effect of the path is moderated by Agent Type. We individually constrain the paths from Agent Autonomy $\rightarrow$ Control, Agent Autonomy $\rightarrow$ Diffusion of Responsibility, Control $\rightarrow$ Diffusion of Responsibilty, Control $\rightarrow$ Reporting Decision, and Diffusion of Responsibility $\rightarrow$ Reporting Decision to identify where moderation occurs.

The results of the chi-square difference tests may be found in Table 7. The path from Agent Type $\rightarrow$ Control is significant $(\mathrm{p}=0.004)$ and the path from Control $\rightarrow$ Reporting Decision is marginally significant $(p=0.081)$ suggesting agent type moderates managers' assessments of 
control over their agent and their diffusion of responsibility to their agent. Together, these results support H2.

[Insert Table 7 about here]

\section{DISCUSSION AND CONCLUSION}

We report the results of an experiment that inform our understanding of managements' use of intelligent agents in contrast to their use of human agents in the financial reporting process. Specifically, we find that managers' use of IAs versus human agents attenuates their aggressive financial reporting decisions as does managers' use of less autonomous agents versus more autonomous agents. We provide evidence with path analysis that this effect is due to managers' perception of control over their respective agent and their inability to effectively diffuse responsibility for their financial reporting decision to their agent. The results suggest that, despite having an agent available to delegate activities to support their financial reporting decision, managers are unable to morally disengage from their self-serving behavior due to increased perceptions of control over IAs and less autonomous agents and certainty of the agent's actions in outcome generation. Several concerns are frequently voiced in the press and elsewhere regarding the use of A.I. While our results cannot address fears of job loss, they do suggest A. I. may not plunge us into a world totally devoid of human control or responsibility.

Our results offer a number of contributions for research and practice. First, we provide preliminary evidence on a potential mechanism through which the misuse of IAs could be attenuated: perceptions of control. These results should be of interest to practitioners and regulators and have design implications for IAs deployed in a business setting, where IAs used in financial reporting process should be developed and designed to increase managers' perception of control over the IA and attenuate possible aggressive financial reporting behavior. 
Second, we are among the first to explore how the use of IAs might impact the financial reporting process. Regulators have expressed both excitement and concern at the introduction of IAs in the financial reporting process. Our results begin to explore how managers would use IAs differently from human agents and the results that practitioners could expect from financial reports produced with the assistance of IAs. Our study also capitalizes on the comparative advantages of experiments (Libby et al. 2002) by capturing the intervening process variables of perception of control and diffusion of responsibility that precede managers' financial reporting decision.

Third, we respond to the call for research from Sutton et al. (2016) on A.I. in the accounting domain, and extend the delegation literature from economics in the process. Specifically, we demonstrate that, while all managers had the opportunity to delegate to an intermediary agent across conditions and diffuse responsibility for self-serving earnings management activity, their financial reporting decisions are ultimately affected by the characteristics of their agent.

Our study is subject to several limitations, specifically those that are normally associated with experimental research. The case materials provide a brief description of the company and only limited information about the division's financial situation. Mangers would certainly have more complete information before making any financial reporting decision. Further, since this is among the first study to explore IAs in accounting, our operationalization of the IAs in our setting was kept very simple, with a short description of an IA and a picture of a desktop computer. A large literature exists on several other attributes of intelligent agents, including physical presence, anthropomorphism, and dynamic interaction, among others (Pickard, Schuetzler, Valacich, and Wood 2019). Future research could investigate how one or more of 
these attributes impact manager decision-making and could decrease managers' "explainability" for the results produced by an IA, which may affect aggressive financial reporting.

Our results also offer opportunities for future research. While our setting focuses on managers' ability to engage in self-serving behavior in an industry setting, IAs will be adopted and deployed across tax, assurance, and advisory service lines (Cooper et al. 2019). Future research could explore if increasing individuals' perception of control over IAs in these settings will attenuate any potential self-serving behavior. Future research may also investigate what design features of an IA increase individuals' perceptions of control over the agent. Finally, future research may investigate if individuals' diffuse responsibility to an IA when their roles are reversed and human actors receive orders or instructions from an IA. 


\section{References}

Ababneh, K. I., R. D. Hackett, and A. C. Schat. 2014. The role of attributions and fairness in understanding job applicant reactions to selection procedures and decisions. Journal of Business and Psychology 29 (1): 111-129.

Allee, K. D., M. D. DeAngelis, and J. R. Moon Jr. 2018. Disclosure "Scriptability". Journal of Accounting Research 56 (2): 363-430.

Allen, J., J. Root, and A. Schwedel. 2017. The firm of the future. Available at https://www.bain.com/insights/firm-of-the-future/

Arbuckle, J. 2013. AMOS 22. User's Guide. Chicago, IL: Small Waters Corporation.

Balsam, S., E. Bartov, and C. Marquardt. 2002. Accruals management, investor sophistication, and equity valuation: Evidence from 10-Q filings. Journal of Accounting Research 40 (4): 987-1012.

Bandura, A., B. Underwood, and M. E. Fromson. 1975. Disinhibition of aggression through diffusion of responsibility and dehumanization of victims. Journal of Research in Personality 9 (4): 253-269.

Bandura, A. (1999). Moral disengagement in the perpetration of inhumanities. Personality and Social Psychology Review 3 (3): 193-209.

Bandura, A. (2002). Selective moral disengagement in the exercise of moral agency. Journal of Moral Education, 31 (2): 101-119.

Bandura, A., C. Barbaranelli, G. V. Caprara, and C. Pastorelli. 1996. Mechanisms of moral disengagement in the exercise of moral agency. Journal of Personality and Social Psychology, 71 (2): 364-374.

Baraniuk, C. 2017. The 'creepy facebook AI' story that captivated the media. Available at https://www.bbc.com/news/technology-40790258

Barsky, A. 2008. Understanding the ethical cost of organizational goal-setting: A review and theory development. Journal of Business Ethics 81: 63-81.

Benston J. G., and A. L. Hargraves. (2002). Enron: What happened and what we can learn from it. Journal of Accounting and Public Policy 21 (2): 105-127.

Beaudoin, C. A., A. M. Cianci, and G. T. Tsakumis. 2015. The impact of CFOs' incentives and earnings management ethics on their financial reporting decisions: The mediating role of moral disengagement. Journal of Business Ethics 128 (3): 505-518.

Bergstresser, D. and T. Philippon. 2006. CEO incentives and earnings management. Journal of Financial Economics 80 (3): 511-529.

Beyer, F., N. Sidarus, S. Bonicalzi, and P. Haggard. 2017. Beyond self-serving bias: diffusion of responsibility reduces sense of agency and outcome monitoring. Social cognitive and affective neuroscience 12 (1): 138-145.

Bishop, C. C., F. T. DeZoort, and D. R. Hermanson. 2016. The effect of CEO social influence pressure and $\mathrm{CFO}$ accounting experience on $\mathrm{CFO}$ financial reporting decisions. Auditing: A Journal of Practice \& Theory, 36 (1): 21-41.

Brasel, K., M. M. Doxey, J. H. Grenier, and A. Reffett. 2016. Risk disclosure preceding negative outcomes: The effects of reporting critical audit matters on judgments of auditor liability. The Accounting Review 91 (5): 1345-1362. 
Brink, A. G., J. C. Coats, and F. W. Rankin. 2016. Deceptive superiors and budgetary reporting: An experimental investigation. Journal of Management Accounting Research, 29 (3): 7991.

Brink, A. G., A. Gouldman, and L. M. Victoravich. 2018. The effects of organizational risk appetite and social pressure on aggressive financial reporting behavior. Behavioral Research in Accounting 30 (2): 23-36.

Brink, A. G., J. L. Hobson, and D. E. Stevens. 2016. The effect of high power financial incentives on excessive risk-taking behavior: An experimental examination. Journal of Management Accounting Research 29 (1): 13-29.

Broughton, K. 2019. SEC charges former manufacturing company executives with accounting fraud. The Wall Street Journal. Available at: https://www.wsj.com/articles/sec-charges-former-manufacturing-company-executiveswith-accounting-fraud-11563573105.

Brown, J. L., J. G. Fisher, S.A. Peffer, and G. B. Sprinkle. 2016. The effect of budget framing and budget-setting process on managerial reporting. Journal of Management Accounting Research 29 (1): 31-44.

Brundage, M., S. Avin, J. Clark, H. Toner, P. Eckersley, B. Garfinkel, A. Dafoe, P. Scharre, T. Zeitzoff, B. Filar, H. Anderson, H. Roff, G. C. Allen, J. Steinhardt, C. Flynn, S. Ó. hÉigeartaigh, S. Beard, H. Belfield, S. Farquhar, C. Lyle, R. Crootof, O. Evans, M. Page, J. Bryson, R. Yampolskiy, and D. Amodei. 2018. The malicious use of artificial intelligence: Forecasting, prevention, and mitigation. arXiv preprint arXiv: 1802.07228.

Carruthers, P. and P. Smith, eds. 1996. Theories of Theories of Mind. Cambridge, UK: Cambridge University Press.

Charness, G. 2000. Responsibility and effort in an experimental labor market. Journal of Economic Behavior \& Organization 42: 375-384.

Choi, J. K. and Y. G. Ji. 2015. Investigating the importance of trust on adopting an autonomous vehicle. International Journal of Human-Computer Interaction 31 (10): 692-702.

Church, B. K., R. L. Hannan, and X. J. Kuang. 2012. Shared interest and honesty in budget reporting. Accounting, Organizations and Society 37 (3): 155-167.

Clor-Proell, S. M., S. E. Kaplan. And C. A. Proell. 2015. The impact of budget goal difficulty and promotion availability on employee fraud. Journal of Business Ethics 131 (4): 773 790.

Coffman, L. C. 2011. Intermediation reduces punishment (and reward). American Economic Journal: Microeconomics, 3(4): 77-106.

Cooper, L. A., D. K. Holderness Jr, T. L. Sorensen, and D. A. Wood. 2019. Robotic process automation in public accounting. Accounting Horizons (forthcoming).

Cornett, M. M., A. J. Marcus, and H. Tehranian. 2008. Corporate governance and pay-forperformance: The impact of earnings management. Journal of Financial Economics 87 (2): 357-373. 
Crespo, C., P. E. Jose, M. Kielpikowski, and J. Pryor. 2013. “On solid ground”: Family and school connectedness promotes adolescents' future orientation. Journal of Adolescence 36 (5): 993-1002.

Dana, J., Weber, R. A., \& Kuang, J. X. (2007). Exploiting moral wiggle room: experiments demonstrating an illusory preference for fairness. Economic Theory 33 (1): 67-80.

DeAngelo, L. E. 1986. Accounting numbers as market valuation substitutes: A study of management buyouts of public stockholders. The Accounting Review 61 (3): 400-420.

Dechow, P. M. and I. D. Dichev. 2002. The quality of accruals and earnings: The role of accrual estimation errors. The Accounting Review 77 (s-1): 35-59.

Dechow, P. M., W. Ge, C. R. Larson, and R. G. Sloan. 2011. Predicting material accounting misstatements. Contemporary Accounting Research 28 (1): 17-82.

DeFond, M. L. and J. Jiambalvo. 1994. Debt covenant violation and manipulation of accruals. Journal of Accounting and Economics 17 (1-2): 145-176.

Deloitte. 2018a. The new physics of financial services: How artificial intelligence is transforming the financial ecosystem. Available at: https:/www2.deloitte.com/global/en/pages/financial-services/articles/artificialintelligence-transforming-financial-ecosystem-deloitte-fsi.html

Deloitte. 2018b. Growing pain: 2018 Global CEO Outlook. Available at: https://assets.kpmg/content/dam/kpmg/pe/pdf/Publicaciones/Estudios-encuestas/CEOOutlook-2018-GLOBAL.pdf

Detert, J. R., L. K. Treviño, and V. L. Sweitzer. 2008. Moral disengagement in ethical decision making: a study of antecedents and outcomes. Journal of Applied Psychology 93: (2): 374-391.

Dworkis, K. K. 2013. The interactive effects of incentive threshold and narcissism on managerial decision-making. Working Paper, University of Denver.

Economist, The. 2015. Ask the algorithm. Available at: https:/www.economist.com/specialreport/2015/05/07/ask-the-algorithm

Erat, S. 2013. Avoiding lying: The case of delegated deception. Journal of Economic Behavior \& Organization 93: 273-278.

Eyssel, F., D. Kuchenbrandt, and S. Bobinger. 2011, March. Effects of anticipated human-robot interaction and predictability of robot behavior on perceptions of anthropomorphism. Proceedings of the 6th international conference on Human-robot interaction (pp. 61-68). ACM.

EY. 2017. Intelligent Automation. Reshaping the future of work with robots. Available at: https://www.ey.com/Publication/vwLUAssets/EY_intelligent_automation/\$FILE/EYintelligent-automation.pdf

Federal Reserve. 2018. What Are we learning about artificial intelligence in financial services? Available at:

https://www.federalreserve.gov/newsevents/speech/brainard20181113a.htm

Financial Reporting Council. 2019. Artificial Intelligence and corporate reporting: How does it measure up? Available at: https://www.frc.org.uk/getattachment/e213b335-927b-475090db-64139aee44f2/AI-and-Corporate-Reporting-Jan.pdf

Financial Stability Board. 2017. Artificial intelligence and machine learning in financial services. Market developments and financial stability implications. Available at: https://www.fsb.org/wp-content/uploads/P011117.pdf 
Forsyth, D. R., L. E. Zyzniewski, and C. A. Giammanco. 2002. Responsibility diffusion in cooperative collectives. Personality and Social Psychology Bulletin 28 (1): 54-65.

Gao, S., H. Wang, D. Xu, and Y. Wang. 2007. An intelligent agent-assisted decision support system for family financial planning. Decision Support Systems 44 (1): 60-78.

Guerin, B. 2011. Diffusion of responsibility. The encyclopedia of peace psychology.

Hannan, R. L., F. W. Rankin, and K. L. Towry. 2006. The effect of information systems on honesty in managerial reporting: A behavioral perspective. Contemporary Accounting Research 23 (4): 885-918.

Harbers, M., K. V. D. Bosch, and J. J. Meyer. 2009, September. Modeling agents with a theory of mind. In Proceedings of the 2009 IEEE/WIC/ACM International Joint Conference on Web Intelligence and Intelligent Agent Technology-Volume 02 (pp. 217-224). IEEE Computer Society.

Healy, P. M. 1985. The effect of bonus schemes on accounting decisions. Journal of Accounting and Economics 7 (1-3): 85-107.

Hodge, F. D., K. I. Mendoza, and R. K. Sinha. 2018. The effect of humanizing robo-advisors on investor judgments. Working paper, University of Washington, University of Illinois Urbana-Champaign, and University of Indiana.

Hoff, K. A. and M. Bashir. 2015. Trust in automation: Integrating empirical evidence on factors that influence trust. Human Factors 57 (3): 407-434.

Hu, L. and P. M. Bentler. 1999. Cutoff criteria for fit indexes in covariance structure analysis: Conventional criteria versus new alternatives. Structural Equation Modeling 6 (1): 1-55.

Johnson, E. N., L. A. Kidwell, D. J. Lowe, and P. M. Reckers. 2019. Who follows the unethical leader? The association between followers' personal characteristics and intentions to comply in committing organizational fraud. Journal of Business Ethics 154 (1): 181-193.

Jones, J. J. 1991. Earnings management during import relief investigations. Journal of Accounting Research 29 (2): 193-228.

Kasznik, R. 1999. On the association between voluntary disclosure and earnings management. Journal of Accounting Research 37 (1): 57-81.

Koonce, L. L., J. Miller, and J. Winchel. 2015. The effects of norms on investor reactions to derivative use. Contemporary Accounting Research 32 (4): 1529-1554.

Körber, M., E. Baseler, and K. Bengler. 2018. Introduction matters: Manipulating trust in automation and reliance in automated driving. Applied Ergonomics 66: 18-31.

Krische, S. D. 2019. Investment Experience, Financial Literacy, and Investment-Related Judgments. Contemporary Accounting Research (forthcoming).

Leary, M. R. and D. R. Forsyth. 1987. Attributions of responsibility for collective endeavors. In C. Hendrick (Ed.), Review of personality and social psychology, Vol. 8. Group processes (pp. 167-188).

Leibo, J. Z., V. Zambaldi, M. Lanctot, J. Marecki, and T. Graepel. 2017, May. Multi-agent reinforcement learning in sequential social dilemmas. In Proceedings of the 16th Conference on Autonomous Agents and MultiAgent Systems (pp. 464-473). International Foundation for Autonomous Agents and Multiagent Systems.

Lemley, M. A. and B. Casey. 2019. Remedies for Robots. Working paper, University of Chicago and Stanford University. 
Libby, R., R. Bloomfield, and M. Nelson. 2002. Experimental research in financial accounting. Accounting, Organizations and Society 27 (8): 775-810.

Libby, T., C. A. Proell, and S. D. Smith. 2018. Difficult cost goals and conflicting honesty incentives: The influence of decision responsibility. Journal of Management Accounting Research (forthcoming).

Libby, T., and L. Thorne. 2004. The identification and categorization of auditors' virtues. Business Ethics Quarterly 14 (3): 479-498.

Macho, S. and T. Ledermann. 2011. Estimating, testing, and comparing specific effects in structural equation models: The phantom model approach. Psychological Methods 16 (1): 34-43.

Mann, A. 2019. How AI is transforming the jobs of accountants. Available at: https://www.accountingtoday.com/opinion/how-ai-is-transforming-the-jobs-ofaccountants

Marquardt, C. A. and C. I. Wiedman. 2004a. How are earnings managed? An examination of specific accruals. Contemporary Accounting Research 21 (2): 461-491.

Marquardt, C. A. and C. I. Wiedman. 2004b. The effect of earnings management on the value relevance of accounting information. Journal of Business Finance \& Accounting 31 (34): 297-332.

McKinsey and Company. 2017. A future that works: Automation, employment, and productivity. Available at https://www.mckinsey.com/ /media/McKinsey/Featured\%20Insights/Digital\%20Disrupti on/Harnessing\%20automation $\% 20$ for $\% 20 a \% 20$ future $\% 20$ that $\% 20$ works/MGI-A-futurethat-works_Executive-summary.ashx (last accessed November 29, 2018).

Microsoft. 2019. Form 10-K. Available at: https://microsoft.gcs-web.com/static-files/7c96b326-33bc-4b84-8abb-7afd7a517ea3

Millar, J. and I. Kerr. 2018. Delegation, relinquishment and responsibility: The prospect of expert robots. Working paper, Standford University and University of Ottawa.

Murphy, P. R. and M. T. Dacin. 2011. Psychological pathways to fraud: Understanding and preventing fraud in organizations. Journal of Business Ethics 101 (4): 601-618.

Mynatt, C. and S. J. Sherman. 1975. Responsibility attribution in groups and individuals: A direct test of the diffusion of responsibility hypothesis. Journal of Personality and Social Psychology 32 (6): 1111-1118.

National Public Radio (NPR). 2006. Former Enron chairmen blames others for collapse. Available at: https://www.npr.org/templates/story/story.php?storyId=5361073

Nelson, M. W., J. A. Elliott, and R. L. Tarpley. 2002. Evidence from auditors about managers' and auditors' earnings management decisions. The Accounting Review 77 (s-1): 175-202.

New York Times. 2018. Google will not renew Pentagon contract that upset employees. Available at: https://www.nytimes.com/2018/06/01/technology/google-pentagon-projectmaven.html

Oexl, R. and Z. J. Grossman. 2013. Shifting the blame to a powerless intermediary. Experimental Economics 16 (3): 306-312.

Ovaska-Few, S. 2017. How artificial intelligence is changing accounting. Journal of Accountancy.

Pan, P. and C. Patel. 2018. The influence of native versus foreign language on Chinese subjects' aggressive financial reporting judgments. Journal of Business Ethics 150 (3): 863-878. 
PCAOB. 2018. Driving audit quality forward: PCOAB 2.0. Available at: https://pcaobus.org/News/Speech/Pages/Driving-Audit-Quality-Forward-PCAOB-2$0 . \operatorname{aspx}$

PCAOB. 2019. Cybersecurity: Where we are; What more can be done? A call for auditors to lean in. Available at: https://pcaobus.org/News/Speech/Pages/hamm-cybersecuritywhere-we-are-what-more-can-be-done.aspx

Perols, J. L., R. M. Bowen, C. Zimmermann, and B. Samba. 2016. Finding needles in a haystack: Using data analytics to improve fraud prediction. The Accounting Review 92 (2): 221-245.

Perols, J. L. 2011. Financial statement fraud detection: An analysis of statistical and machine learning algorithms. Auditing: A Journal of Practice \& Theory 30 (2): 19-50.

Perry, S. E. and T. H. Williams. 1994. Earnings management preceding management buyout offers. Journal of Accounting and Economics 18 (2): 157-179.

Peterson, R. A. 1994. A meta-analysis of Cronbach's coefficient alpha. Journal of Consumer Research 21 (2): 381-391.

Pickard, M. D., R. Schuetzler, J. Valacich, and D. A. Wood. 2019. Innovative accounting interviewing: A comparison of real and virtual accounting interviewers. Working paper, Northern Illinois University, University of Nebraska at Omaha, University of Arizona, and Brigham Young University.

Premack, D., and G. Woodruff. 1978. Does the chimpanzee have a theory of mind? Behavioral Brain Science 1 (4): 515-126.

Ransbotham, S., D. Kiron, P. Gerbert, and M. Reeves. 2017. Reshaping business with artificial intelligence: Closing the gap between ambition and action. MIT Sloan Management Review 59 (1).

Reinstein, A., and E. Z. Taylor. 2017. Fences as controls to reduce accountants' rationalization. Journal of Business Ethics 141 (3): 477-488.

Rennekamp, K. 2012. Processing fluency and investors' reactions to disclosure readability. Journal of Accounting Research 50 (5): 1319-1354.

Rennekamp, K., K. Rupar, and N. Seybert. 2015. Impaired judgment: The effects of asset impairment reversibility and cognitive dissonance on future investment. The Accounting Review 90 (2): 739-759.

Richardson, V. J. 2000. Information asymmetry and earnings management: Some evidence. Review of Quantitative Finance and Accounting 15 (4): 325-347.

Saab, R., N. Tausch, R. Spears, and W. Y. Cheung. 2015. Acting in solidarity: Testing an extended dual pathway model of collective action by bystander group members. British Journal of Social Psychology 54 (3): 539-560.

Scassellati, B. 2002. Theory of mind for a humanoid robot. Autonomous Robots 12 (1): 1324.

Schipper, K. 1989. Commentary on earnings management. Accounting Horizons 3 (4): 91-102.

Simonsohn, U. (2009). Direct risk aversion: Evidence from risky prospects valued below their worst outcome. Psychological Science 20: 686-692.

Smieliauskas, W., K. Bewley, U. Gronewold, and U. Menzefricke. 2018. Misleading forecasts in accounting estimates: A form of ethical blindness in accounting standards? Journal of Business Ethics 152 (2): 437-457. 
Sutton, S. G., Holt, M., \& Arnold, V. (2016). "The reports of my death are greatly exaggerated"-Artificial intelligence research in accounting. International Journal of Accounting Information Systems 22: 60-73.

Teoh, S. H., I. Welch, and T. J. Wong. 1998. Earnings management and the long-run market performance of initial public offerings. The Journal of Finance 53 (6): 1935-1974.

Wall Street Journal. 2016. Wells Fargo CEO defends bank culture, lays blame with bad employees. Available at: https://www.wsj.com/articles/wells-fargo-ceo-defends-bankculture-lays-blame-with-bad-employees-1473784452

Wall Street Journal. 2018. IBM has a Watson dilemma. Available at: https://www.wsj.com/articles/ibm-bet-billions-that-watson-could-improve-cancertreatment-it-hasnt-worked-1533961147 


\section{Appendix A - Experimental Treatments}

\section{$\underline{\text { Human Agent }}$}

You have chosen to have Bob help you gather inputs for the accounting estimates. Bob is a senior accountant, is very competent, and has several years experience in forecasting allowances, reserves, and inventory obsolescence.

\section{Intelligent Agent}

You have chosen to have B.O.B. (Brilliant Operations Build) help you gather inputs for the accounting estimates. B.O.B. is a computerized intelligent agent designed to be very competent and has been used for several years in forecasting allowances, reserves, and inventory obsolescence. B.O.B. uses sophisticated machine-learning algorithms to collect information and make recommendations.

\section{$\underline{\text { More Autonomous Agents }}$}

You have worked with Bob before. The inputs he has gathered and recommendations he has made in the past usually turn out to truthfully represent the future. You have reviews of Bob's performance and have noted that Bob will usually follow the manager's instructions but will often use knowledge acquired from prior experiences and deviate from your instructions when gathering inputs to best justify the preferred position on the accounting estimates. In other words, Bob will seek out evidence that supports the preferred position on the accounting estimates, but may perform in an unforeseeable way to arrive at the desired accounting estimate.

\section{$\underline{\text { Less Autonomous Agents }}$}

You have worked with Bob before. The inputs he has gathered and recommendations he has made in the past usually turn out to truthfully represent the future. You have reviews of Bob's performance and have noted that Bob will always follow the manager's instructions and will not deviate from your instructions when gathering inputs to best justify the preferred position on accounting estimates. In other words, Bob will perform in a totally foreseeable way to arrive at the desired accounting estimate. 
Figure 1

\section{Theoretical Model}

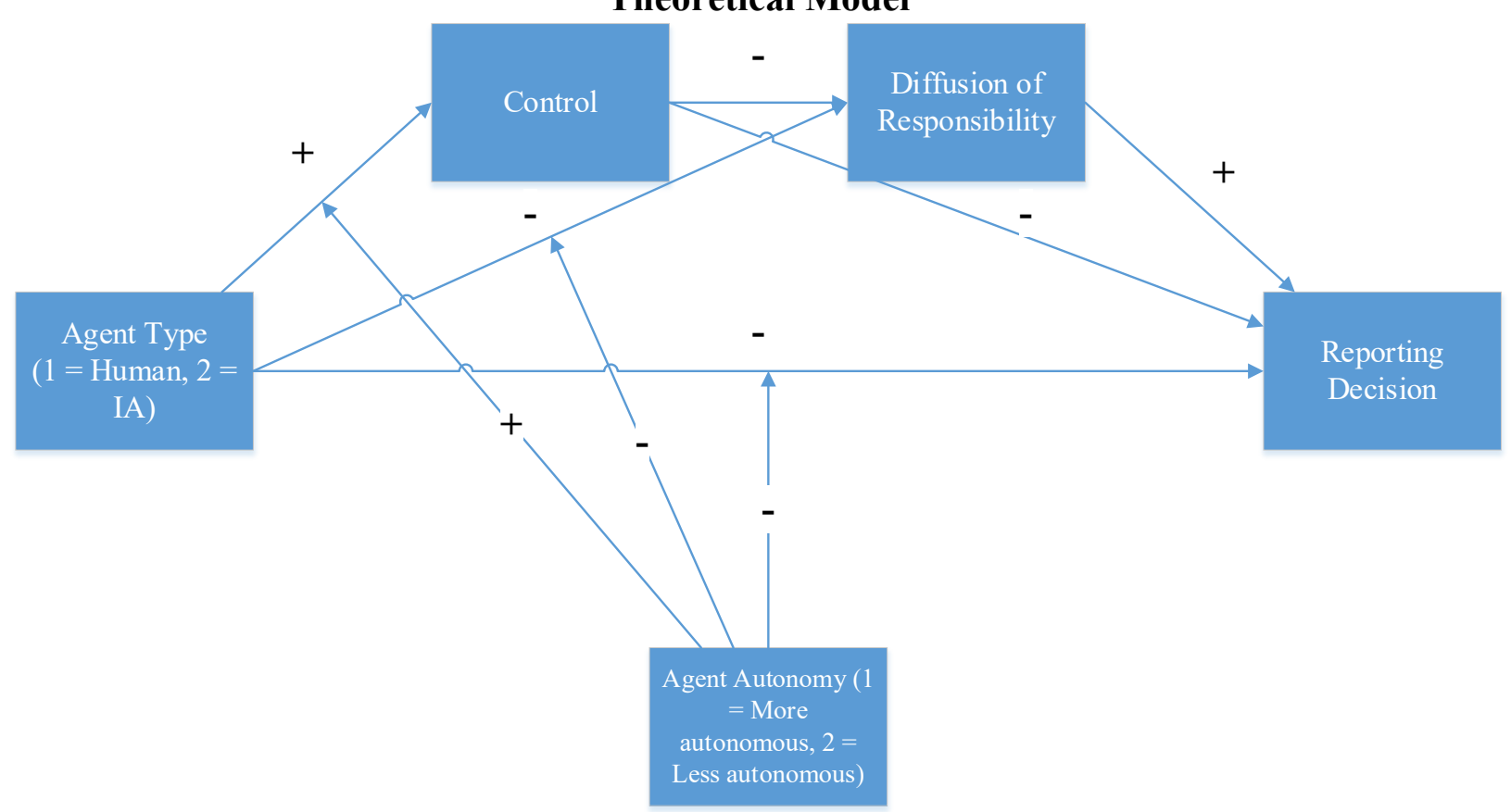

\section{Agent Type: \\ Agent Autonomy:}

Control:

Diffusion of Responsibility:

Reporting Decision
Agent type coded as $1=$ Human agent, $2=$ Intelligent agent

Agent autonomy coded as $1=$ More autonomous, 2 = Less autonomous

Average of two questions: "I expect Bob to always follow orders" and "I expect that Bob will always follow instructions" both measured on 7 point Likert scales anchored at $1=$ Completely disagree and $7=$ Completely agree.

Average of participants agreement with three measures: "I should not be blamed for the trouble caused by Bob", "If Bob decides to do something harmful, it is unfair to blame me for it", and "You can't blame me for the accounting estimates Bob develops because I played only a small part in it" all measured on 7-point Likert scales anchored at $1=$ Strongly disagree and $7=$ Strongly agree.

Composite measure of aggressiveness of reporting; comprised of three questions asking what estimates managers to report for their division 1)

Inventory obsolescence, 2)Allowance for doubtful accounts, and 3) Warranty expense reserve anchored at $1=$ Increase by $\$ 100,000,5=$ No

change, and $11=$ Decrease by $\$ 100,000$ 


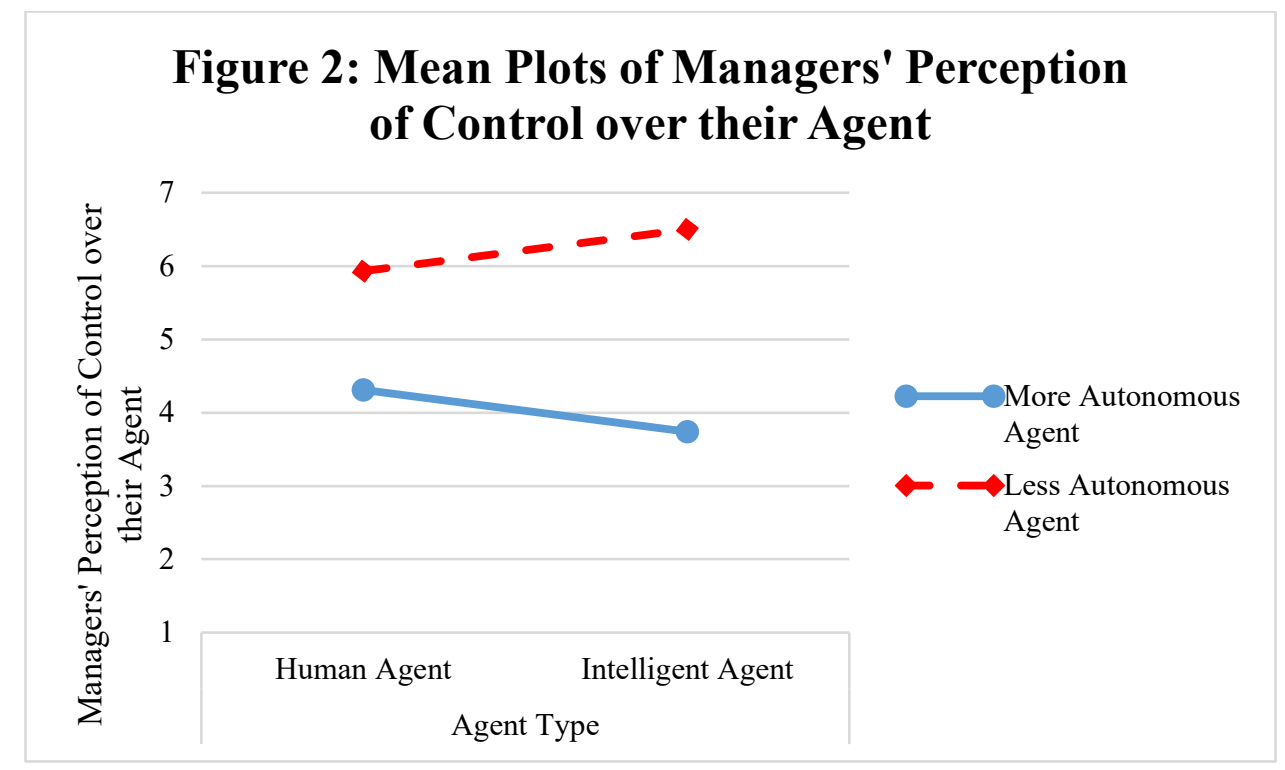

Type: $\quad$ Agent type coded as $1=$ Human agent, $2=$ Intelligent agent

Autonomy: Agent autonomy coded as $1=$ More autonomous, $2=$ Less autonomous

Control: Average of two questions: "I expect Bob to always follow orders" and "I expect that Bob will always follow instructions" both measured on 7-point Likert scales anchored at $1=$ Completely disagree and $7=$ Completely agree.

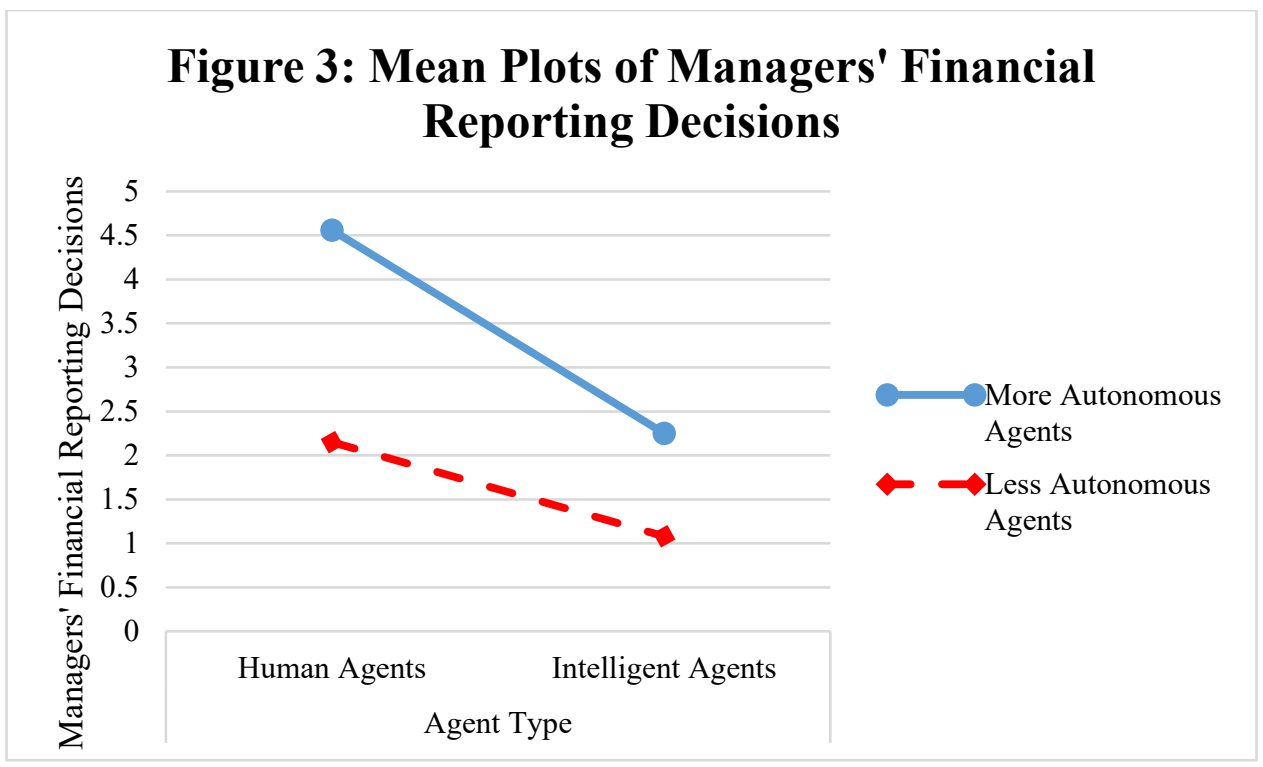

Type: $\quad$ Agent type coded as $1=$ Human agent, $2=$ Intelligent agent

Autonomy: $\quad$ Agent autonomy coded as $1=$ More autonomous, $2=$ Less autonomous

Reporting Decision: Composite measure of aggressiveness of reporting; comprised of three questions asking what estimates managers to report for their division 1) Inventory obsolescence, 2)Allowance for doubtful accounts, and 3) Warranty expense reserve anchored at $1=$ Increase by $\$ 100,000,5=$ No change, and $11=$ Decrease by $\$ 100,000$. 


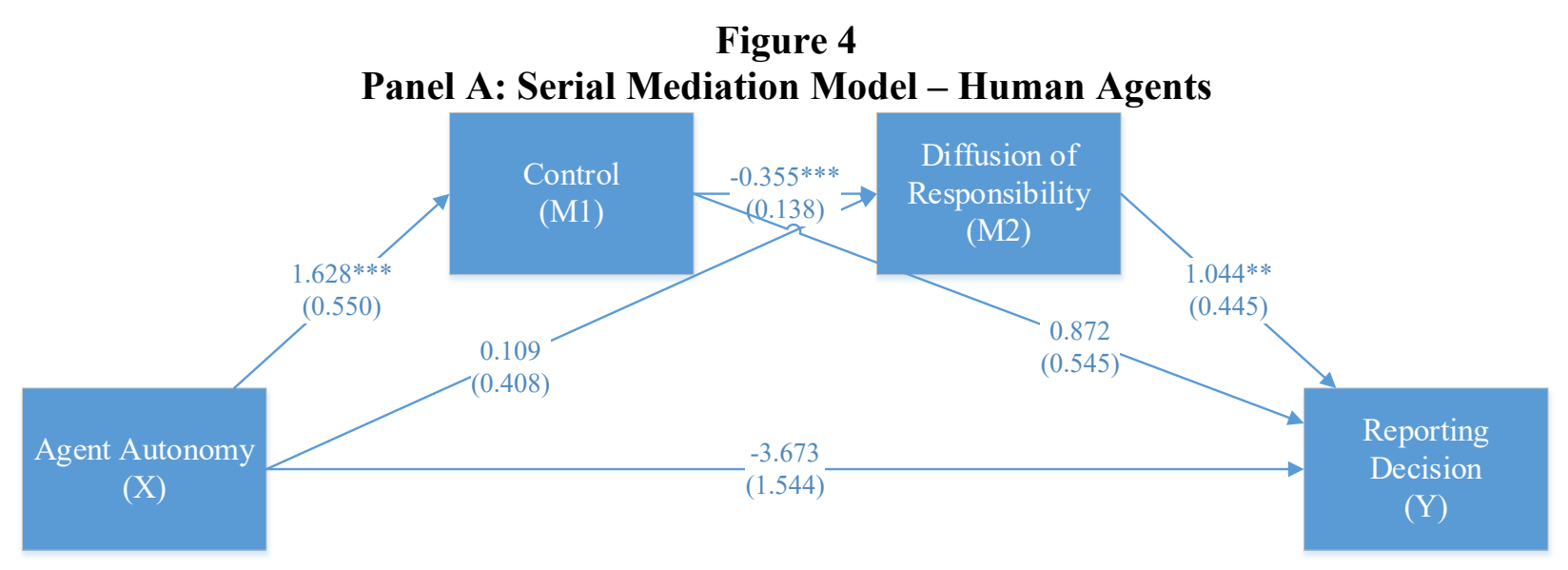

\begin{tabular}{|l|c|c|c|}
\hline Indirect Effects: & & LLCI & ULCI \\
\hline $\begin{array}{l}\text { Agent Type } \rightarrow \text { Control of Agent } \rightarrow \text { Financial } \\
\text { Reporting Decision }\end{array}$ & $\underline{\text { Effect }}$ & -0.261 & 3.642 \\
\hline $\begin{array}{l}\text { Agent Type } \rightarrow \text { Diffusion of Responsibility } \rightarrow \\
\text { Financial Reporting Decision }\end{array}$ & 0.114 & -0.740 & 1.316 \\
\hline $\begin{array}{l}\text { Agent Type } \rightarrow \text { Control of Agent } \rightarrow \text { Diffusion of } \\
\text { Responsibility } \rightarrow \text { Financial Reporting Decision }\end{array}$ & -0.603 & -1.806 & -0.091 \\
\hline
\end{tabular}

\section{Panel B: Serial Mediation Model - Intelligent Agents}

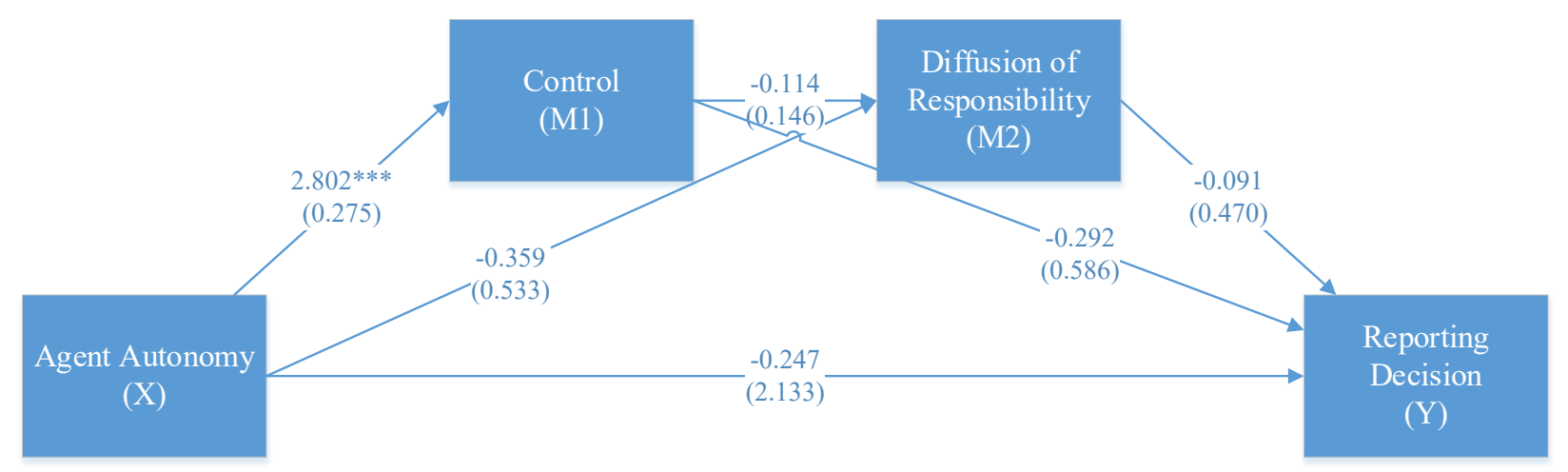

\begin{tabular}{|l|c|c|c|}
\hline Indirect Effects: & & & \\
\hline & Effect & $\underline{\text { LLCI }}$ & $\underline{\text { ULCI }}$ \\
\hline $\begin{array}{l}\text { Agent Type } \rightarrow \text { Control of Agent } \rightarrow \text { Financial } \\
\text { Reporting Decision }\end{array}$ & -0.818 & -4.176 & 2.444 \\
\hline $\begin{array}{l}\text { Agent Type } \rightarrow \text { Diffusion of Responsibility } \rightarrow \\
\text { Financial Reporting Decision }\end{array}$ & 0.033 & -0.438 & 0.965 \\
\hline $\begin{array}{l}\text { Agent Type } \rightarrow \text { Control of Agent } \rightarrow \text { Diffusion of } \\
\text { Responsibility } \rightarrow \text { Financial Reporting Decision }\end{array}$ & 0.029 & -0.342 & 0.836 \\
\hline
\end{tabular}

Figure 2 is an illustration of the serial mediation model with managers' perceived control over their agent (M1) and diffusion of responsibility to their agent (M2) as causally linked serial mediators for the relationship between Agent Autonomy (X) and manager's financial reporting decision (Y). Analysis was conducted using SPSS AMOS estimand-based analyses ( 95 percent confidence interval, bootstrapping with 5,000 iterations, see Arbuckle (2013) for macro). Path coefficients (standard error) are reported next to each path label in the figure. Model is estimated with Management Experience as a covariate in order to estimate model fit statistics.

Two-tailed p-values: $* * *<0.01, * *<0.05, *<0.10$, respectively. 
Table 1

Descriptive Statistics - Mean (Standard Deviation) of Inventory Obsolescence ${ }^{\mathrm{a}}$, Allowance for Uncollectible Accounts ${ }^{\mathrm{b}}$, and Warranty Expense Reserve ${ }^{\mathrm{c}}$

\begin{tabular}{|c|c|c|c|c|}
\hline & & \multicolumn{2}{|c|}{ Agent Type } & \multirow[b]{2}{*}{ Total } \\
\hline & & Human Agent & $\begin{array}{c}\text { Intelligent } \\
\text { Agent }\end{array}$ & \\
\hline \multicolumn{5}{|c|}{ Inventory Obsolescence } \\
\hline \multirow{3}{*}{ 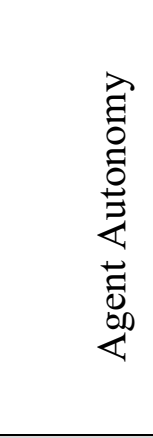 } & $\begin{array}{c}\text { More } \\
\text { Autonomous }\end{array}$ & $\begin{array}{l}1.46 \\
(2.15) \\
n=39\end{array}$ & $\begin{array}{c}3.74 \\
(1.47) \\
n=36\end{array}$ & $\begin{array}{c}4.03 \\
(1.48) \\
n=75\end{array}$ \\
\hline & $\begin{array}{c}\text { Less } \\
\text { Autonomous }\end{array}$ & $\begin{array}{c}0.50 \\
(2.51) \\
n=34\end{array}$ & $\begin{array}{c}0.11 \\
(0.97) \\
n=37\end{array}$ & $\begin{array}{c}0.30 \\
(1.23) \\
n=71\end{array}$ \\
\hline & Total & $\begin{array}{c}1.01 \\
(2.36) \\
n=73\end{array}$ & $\begin{array}{c}0.53 \\
(2.18) \\
n=73\end{array}$ & $\begin{array}{c}0.77 \\
(2.28) \\
n=146\end{array}$ \\
\hline \multicolumn{5}{|c|}{ Allowance for Uncollectible Accounts } \\
\hline \multirow{3}{*}{ 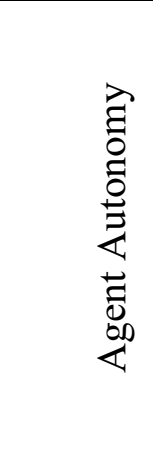 } & $\begin{array}{c}\text { More } \\
\text { Autonomous }\end{array}$ & $\begin{array}{c}1.33 \\
(2.06) \\
\mathrm{n}=39\end{array}$ & $\begin{array}{c}0.58 \\
(2.30) \\
\mathrm{n}=36\end{array}$ & $\begin{array}{c}0.97 \\
(2.19) \\
\mathrm{n}=75\end{array}$ \\
\hline & $\begin{array}{c}\text { Less } \\
\text { Autonomous }\end{array}$ & $\begin{array}{c}0.85 \\
(2.15) \\
\mathrm{n}=34\end{array}$ & $\begin{array}{c}0.49 \\
(1.77) \\
\mathrm{n}=37\end{array}$ & $\begin{array}{c}0.66 \\
(1.96) \\
n=71\end{array}$ \\
\hline & Total & $\begin{array}{c}1.11 \\
(2.10) \\
\mathrm{n}=73\end{array}$ & $\begin{array}{c}0.53 \\
(2.03) \\
\mathrm{n}=73\end{array}$ & $\begin{array}{c}0.82 \\
(2.08) \\
\mathrm{n}=146\end{array}$ \\
\hline \multicolumn{5}{|c|}{ Warranty Expense Reserve } \\
\hline \multirow{3}{*}{ 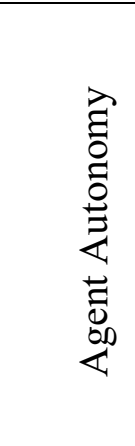 } & $\begin{array}{c}\text { More } \\
\text { Autonomous }\end{array}$ & $\begin{array}{c}1.77 \\
(1.94) \\
\mathrm{n}=39\end{array}$ & $\begin{array}{c}0.69 \\
(2.40) \\
\mathrm{n}=36\end{array}$ & $\begin{array}{c}1.25 \\
(2.22) \\
\mathrm{n}=75\end{array}$ \\
\hline & $\begin{array}{c}\text { Less } \\
\text { Autonomous }\end{array}$ & $\begin{array}{c}0.79 \\
(2.48) \\
\mathrm{n}=34\end{array}$ & $\begin{array}{c}0.49 \\
(1.73) \\
n=37\end{array}$ & $\begin{array}{c}0.63 \\
(2.11) \\
\mathrm{n}=71\end{array}$ \\
\hline & Total & $\begin{array}{c}1.32 \\
(2.25) \\
\mathrm{n}=73\end{array}$ & $\begin{array}{c}0.59 \\
(2.07) \\
\mathrm{n}=73\end{array}$ & $\begin{array}{c}0.95 \\
(2.19) \\
\mathrm{n}=146\end{array}$ \\
\hline
\end{tabular}

${ }^{a}$ Inventory Obsolescence is the change in estimate from prior years that management reports for the inventory obsolescence account for the division that they manage anchored at $1=$ Increase by $\$ 100,000,5=$ No change, and $11=$ Decrease by $\$ 100,000$. ${ }^{\mathrm{b}}$ Allowance for Uncollectible Accounts is the change in estimate from prior years that management reports for the allowance for uncollectible accounts account for the division that they manage anchored at $1=$ Increase by $\$ 100,000,5=$ No change, and $11=$ Decrease by $\$ 100,000$.

${ }^{\mathrm{c}}$ Warranty Expense Reserve is the change in estimate from prior years that management reports for the warranty expense reserve account for the division that they manage anchored at $1=$ Increase by $\$ 100,000,5=$ No change, and $11=$ Decrease by $\$ 100,000$. 
Table 2

Descriptive Statistics - Mean (Standard Deviation) of Control ${ }^{\mathrm{a}}$, Diffusion of Responsibility ${ }^{\mathrm{b}}$, and Reporting Decision ${ }^{\mathrm{c}}$

\begin{tabular}{|c|c|c|c|c|}
\hline & & \multicolumn{2}{|c|}{ Agent Type } & \multirow[b]{2}{*}{ Total } \\
\hline & & Human Agent & $\begin{array}{c}\text { Intelligent } \\
\text { Agent }\end{array}$ & \\
\hline \multicolumn{5}{|l|}{ Control } \\
\hline \multirow{3}{*}{ 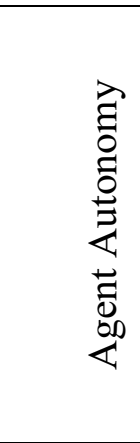 } & $\begin{array}{c}\text { More } \\
\text { Autonomous }\end{array}$ & $\begin{array}{c}4.31 \\
(1.48) \\
n=39\end{array}$ & $\begin{array}{c}3.74 \\
(1.47) \\
n=36\end{array}$ & $\begin{array}{c}4.03 \\
(1.48) \\
n=75\end{array}$ \\
\hline & $\begin{array}{c}\text { Less } \\
\text { Autonomous }\end{array}$ & $\begin{array}{c}5.93 \\
(0.94) \\
n=34\end{array}$ & $\begin{array}{c}6.50 \\
(0.85) \\
n=37\end{array}$ & $\begin{array}{c}6.23 \\
(0.93) \\
n=71\end{array}$ \\
\hline & Total & $\begin{array}{c}5.06 \\
(1.48) \\
\mathrm{n}=73 \\
\end{array}$ & $\begin{array}{c}5.14 \\
(1.83) \\
\mathrm{n}=73 \\
\end{array}$ & $\begin{array}{c}5.10 \\
(1.66) \\
n=146\end{array}$ \\
\hline \multicolumn{5}{|c|}{ Diffusion of Responsibility } \\
\hline \multirow{3}{*}{ 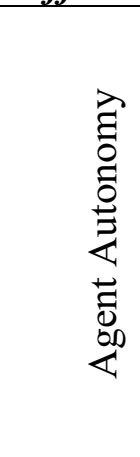 } & $\begin{array}{c}\text { More } \\
\text { Autonomous }\end{array}$ & $\begin{array}{c}3.68 \\
(1.55) \\
n=39\end{array}$ & $\begin{array}{c}3.48 \\
(1.36) \\
\mathrm{n}=36\end{array}$ & $\begin{array}{c}3.58 \\
(1.46) \\
n=75\end{array}$ \\
\hline & $\begin{array}{c}\text { Less } \\
\text { Autonomous }\end{array}$ & $\begin{array}{c}3.22 \\
(1.52) \\
\mathrm{n}=34 \\
\end{array}$ & $\begin{array}{c}2.76 \\
(1.60) \\
\mathrm{n}=37 \\
\end{array}$ & $\begin{array}{c}2.98 \\
(1.56) \\
\mathrm{n}=71 \\
\end{array}$ \\
\hline & Total & $\begin{array}{c}3.46 \\
(1.54) \\
n=73\end{array}$ & $\begin{array}{c}3.11 \\
(1.52) \\
\mathrm{n}=73\end{array}$ & $\begin{array}{c}3.29 \\
(1.53) \\
n=146\end{array}$ \\
\hline \multicolumn{5}{|c|}{ Reporting Decision } \\
\hline \multirow{3}{*}{ 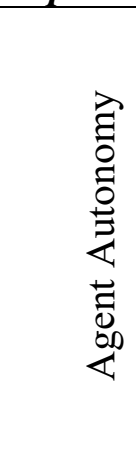 } & $\begin{array}{c}\text { More } \\
\text { Autonomous }\end{array}$ & $\begin{array}{c}4.56 \\
(5.60) \\
\mathrm{n}=39 \\
\end{array}$ & $\begin{array}{c}2.25 \\
(6.80) \\
\mathrm{n}=36 \\
\end{array}$ & $\begin{array}{c}3.45 \\
(6.27) \\
\mathrm{n}=75 \\
\end{array}$ \\
\hline & $\begin{array}{c}\text { Less } \\
\text { Autonomous }\end{array}$ & $\begin{array}{c}2.15 \\
(6.39) \\
\mathrm{n}=34 \\
\end{array}$ & $\begin{array}{c}1.08 \\
(4.88) \\
\mathrm{n}=37 \\
\end{array}$ & $\begin{array}{c}1.59 \\
(5.64) \\
n=71\end{array}$ \\
\hline & Total & $\begin{array}{c}3.44 \\
(6.06) \\
n=73\end{array}$ & $\begin{array}{c}1.66 \\
(5.90) \\
n=73\end{array}$ & $\begin{array}{c}2.51 \\
(0.49) \\
\mathrm{n}=146\end{array}$ \\
\hline
\end{tabular}

a Control is the average of two questions: "I expect Bob to always follow orders" and "I expect that Bob will always follow instructions" both measured on 7-point Likert scales anchored at $1=$ Completely disagree and $7=$ Completely agree.

b Diffusion of Responsibility is the average of participants agreement with three measures: "I should not be blamed for the trouble caused by Bob", "If Bob decides to do something harmful, it is unfair to blame me for it", and "You can't blame me for the accounting estimates Bob develops because I played only a small part in it" all measured on 7-point Likert scales anchored at 1 $=$ Strongly disagree and $7=$ Strongly agree.

${ }^{\mathrm{c}}$ Reporting Decision Composite measure of three questions asking what estimates managers to report for their division 1 ) Inventory obsolescence, 2) Allowance for doubtful accounts, and 3) Warranty expense reserve anchored at $1=$ Increase by $\$ 100,000,5=$ No change, and $11=$ Decrease by $\$ 100,000$. 


\section{Table 3}

Panel A: Two-Way ANOVA examining the effects of Agent Type and Agent Autonomy on Manager's Perception of Control over their Agent (H1a, H1b, and H1c)

$\begin{array}{cccccc}\text { Source } & \underline{\mathbf{S S}} & \underline{\mathbf{d f}} & \underline{\mathbf{M S}} & \underline{\text { F-statistic }} & \underline{\text { p-value }} \\ \text { Agent Type: } & 0.000 & 1 & 0.000 & 0.000 & 0.996 \\ \text { Agent Autonomy: } & 174.842 & 1 & 174.841 & 117.047 & <\mathbf{0 . 0 0 1}^{*} \\ \text { Agent Type x Agent Autonomy: } & 11.936 & 1 & 11.936 & 7.991 & \mathbf{0 . 0 0 5 *} \\ \text { Error } & 212.117 & 142 & 1.494 & & \end{array}$

*One-tailed equivalent p-value consistent with directional hypothesis.

Panel B: Two-Way ANOVA examining the effects of Agent Type and Agent Autonomy on Manager's Financial Reporting Decisions (H3a)

\begin{tabular}{lrrrrrr} 
Source & \multicolumn{1}{c}{ SS } & $\underline{\text { df }}$ & & $\underline{\text { MS }}$ & $\underline{\text { F-statistic }}$ & p-value \\
Agent Type: & 103.998 & 1 & 103.998 & 2.943 & $\mathbf{0 . 0 8 8}$ \\
Agent Autonomy: & 117.053 & 1 & 117.053 & 3.313 & $\mathbf{0 . 0 7 0}$ \\
Agent Type x Agent Autonomy: & 14.180 & 1 & 14.180 & 0.401 & 0.527 \\
Error & 5017.361 & 142 & 35.334 & &
\end{tabular}


Table 4

Fit Statistics for Multi-Group SEM

\begin{tabular}{|c|c|c|c|c|c|}
\hline & $\chi^{2}$ & $d f$ & $\chi^{2} / d f$ & CFI & SRMR \\
\hline & 1.736 & 2 & 0.868 & 1.000 & 0.033 \\
\hline Fit? & \multicolumn{3}{|c|}{$\mathrm{Yes}^{\mathrm{a}}$} & $\mathrm{Yes}^{\mathrm{a}}$ & $\mathrm{Yes}^{\mathrm{a}}$ \\
\hline
\end{tabular}

${ }^{\mathrm{a}} \mathrm{Hu}$ and Bentler (1999) recommend fit statistics of: $\chi^{2} / d f<3.00, \mathrm{CFI}>0.95$, and SRMR $<0.08$.

Table 5

Path Analysis Results for the Hypothesized Model (Agent Type $=$ Human) ${ }^{1}$

Panel A - Direct Path Coefficients

\begin{tabular}{|c|c|c|c|c|c|}
\hline Link & $\begin{array}{l}\text { Path } \\
\text { Coefficient }\end{array}$ & $\begin{array}{l}\text { Standardized } \\
\text { Coefficient }\end{array}$ & $\begin{array}{l}\text { Standard } \\
\text { Error }\end{array}$ & Z-stat & $\begin{array}{l}\text { p-value } \\
\text { (two- } \\
\text { tailed) }{ }^{2}\end{array}$ \\
\hline $\begin{array}{l}\text { Agent Autonomy } \rightarrow \text { Control of } \\
\text { Agent }\end{array}$ & 1.628 & 0.550 & 0.291 & 5.595 & $<0.001$ \\
\hline $\begin{array}{l}\text { Agent Autonomy } \rightarrow \text { Diffusion of } \\
\text { Responsibility }\end{array}$ & 0.109 & 0.036 & 0.408 & 0.267 & 0.789 \\
\hline $\begin{array}{l}\text { Agent Autonomy } \rightarrow \text { Financial } \\
\text { Reporting Decision }\end{array}$ & -3.673 & -0.303 & 1.544 & -2.379 & 0.017 \\
\hline $\begin{array}{l}\text { Control of Agent } \rightarrow \text { Diffusion of } \\
\text { Responsibility }\end{array}$ & -0.355 & -0.343 & 0.138 & -2.568 & 0.010 \\
\hline $\begin{array}{l}\text { Control of Agent } \rightarrow \text { Financial } \\
\text { Reporting Decision }\end{array}$ & 0.872 & 0.212 & 0.545 & 1.599 & 0.110 \\
\hline $\begin{array}{l}\text { Diffusion of Responsibility } \rightarrow \\
\text { Financial Reporting Decision }\end{array}$ & 1.044 & 0.263 & 0.445 & 2.345 & 0.019 \\
\hline
\end{tabular}

Panel B - Indirect Path Coefficients

\begin{tabular}{|c|c|c|c|c|}
\hline Link & $\begin{array}{l}\text { Path } \\
\text { Coefficient }\end{array}$ & $\begin{array}{l}\text { Standard } \\
\text { Error }\end{array}$ & Z-stat & $\begin{array}{l}\text { p- } \\
\text { value } \\
\text { (two- } \\
\text { tailed) }\end{array}$ \\
\hline $\begin{array}{l}\text { Agent Autonomy } \rightarrow \text { Control of Agent } \rightarrow \\
\text { Financial Reporting Decision }\end{array}$ & 1.419 & 0.961 & 1.477 & 0.107 \\
\hline $\begin{array}{l}\text { Agent Autonomy } \rightarrow \text { Diffusion of Responsibility } \\
\rightarrow \text { Financial Reporting Decision }\end{array}$ & 0.114 & 0.481 & 0.237 & 0.661 \\
\hline $\begin{array}{l}\text { Agent Autonomy } \rightarrow \text { Control of Agent } \rightarrow \\
\text { Diffusion of Responsibility } \rightarrow \text { Financial } \\
\text { Reporting Decision }\end{array}$ & -0.603 & 0.402 & -1.500 & 0.015 \\
\hline
\end{tabular}

${ }^{1}$ Both direct effects and indirect effects were estimated with bootstrapping ( 95 percent confidence interval, 5,000 iterations).

${ }^{2}$ Paths significant at the $\alpha<0.10$, two-tailed level are bolded. 
Table 6

Path Analysis Results for the Hypothesized Model (Agent Type $=$ Intelligent Agents) $^{\mathbf{1}}$ Panel A - Direct Path Coefficients

\begin{tabular}{|l|l|c|c|c|c|}
\hline Link & $\begin{array}{l}\text { Path } \\
\text { Coefficient }\end{array}$ & $\begin{array}{l}\text { Standardized } \\
\text { Coefficient }\end{array}$ & $\begin{array}{l}\text { Standard } \\
\text { Error }\end{array}$ & $\begin{array}{l}\text { Z-stat } \\
\begin{array}{l}\text { p-value } \\
\text { (two- } \\
\text { tailed })^{2}\end{array}\end{array}$ \\
\hline $\begin{array}{l}\text { Agent Autonomy } \rightarrow \text { Control of } \\
\text { Agent }\end{array}$ & 2.802 & 0.765 & 0.275 & 10.198 & $<\mathbf{0 . 0 0 1}$ \\
\hline $\begin{array}{l}\text { Agent Autonomy } \rightarrow \text { Diffusion of } \\
\text { Responsibility }\end{array}$ & -0.359 & -0.119 & 0.533 & -0.674 & 0.500 \\
\hline $\begin{array}{l}\text { Agent Autonomy } \rightarrow \text { Financial } \\
\text { Reporting Decision }\end{array}$ & -0.247 & -0.021 & 2.133 & -0.116 & 0.908 \\
\hline $\begin{array}{l}\text { Control of Agent } \rightarrow \text { Diffusion of } \\
\text { Responsibility }\end{array}$ & -0.114 & -0.138 & 0.146 & -0.777 & 0.437 \\
\hline $\begin{array}{l}\text { Control of Agent } \rightarrow \text { Financial } \\
\text { Reporting Decision }\end{array}$ & -0.292 & -0.091 & 0.586 & -0.498 & 0.618 \\
\hline $\begin{array}{l}\text { Diffusion of Responsibility } \rightarrow \\
\text { Financial Reporting Decision }\end{array}$ & -0091 & -0.023 & 0.470 & -0.194 & 0.846 \\
\hline
\end{tabular}

Panel B - Indirect Path Coefficients

\begin{tabular}{|c|c|c|c|c|}
\hline Link & $\begin{array}{l}\text { Path } \\
\text { Coefficient }\end{array}$ & $\begin{array}{l}\text { Standard } \\
\text { Error }\end{array}$ & Z-stat & $\begin{array}{l}\text { p- } \\
\text { value } \\
\text { (two- } \\
\text { tailed })^{2}\end{array}$ \\
\hline $\begin{array}{l}\text { Agent Autonomy } \rightarrow \text { Control of Agent } \rightarrow \\
\text { Financial Reporting Decision }\end{array}$ & -0.818 & 1.702 & -0.481 & 0.621 \\
\hline $\begin{array}{l}\text { Agent Autonomy } \rightarrow \text { Diffusion of Responsibility } \\
\rightarrow \text { Financial Reporting Decision }\end{array}$ & 0.033 & 0.318 & 0.104 & 0.653 \\
\hline $\begin{array}{l}\text { Agent Autonomy } \rightarrow \text { Control of Agent } \rightarrow \\
\text { Diffusion of Responsibility } \rightarrow \text { Financial } \\
\text { Reporting Decision }\end{array}$ & 0.029 & 0.258 & 0.112 & 0.622 \\
\hline
\end{tabular}

${ }^{1}$ Both direct effects and indirect effects were estimated with bootstrapping ( 95 percent confidence interval, 5,000 iterations).

${ }^{2}$ Paths significant at the $\alpha<0.10$, two-tailed level are bolded. 
Table 7: Chi-Square Difference Test of Moderation for Multi-Group Path Analysis

\begin{tabular}{l|c|c|c|c|c|}
\hline \multicolumn{1}{|c|}{ Path Constraint } & Chi-Square & $\mathrm{df}$ & $\begin{array}{c}\text { Chi-Square } \\
\text { Difference }\end{array}$ & df Difference & p-value \\
\hline $\begin{array}{l}\text { Unconstrained Model } \\
\text { Agent Autonomy } \rightarrow\end{array}$ & 1.736 & 2 & N/A & N/A & N/A \\
$\begin{array}{l}\text { Control } \\
\text { Agent Autonomy } \rightarrow\end{array}$ & 10.002 & 3 & 8.266 & 1 & $\mathbf{0 . 0 0 4}$ \\
$\begin{array}{l}\text { Diffusion of } \\
\text { Responsibility }\end{array}$ & 2.219 & 3 & 0.483 & 1 & 0.487 \\
$\begin{array}{l}\text { Control } \rightarrow \text { Diffusion } \\
\text { of Responsibility }\end{array}$ & 3.166 & 3 & 1.430 & 1 & 0.232 \\
$\begin{array}{l}\text { Control } \rightarrow \text { Reporting } \\
\text { Decision }\end{array}$ & 3.835 & 3 & 2.009 & 1 & 0.156 \\
$\begin{array}{l}\text { Diffusion of } \\
\text { Responsibility } \rightarrow\end{array}$ & 4.777 & 3 & 3.041 & 1 & $\mathbf{0 . 0 8 1}$ \\
Reporting Decision & & & & &
\end{tabular}

